Keywords: cell culture; mycoplasma contamination; Human Tissue Act; cell line; cell line misidentification; cryostorage; Human Tissue Authority; STR profiling; human tissue; Human Fertilisation and Embryology Act

\title{
Guidelines for the use of cell lines in biomedical research
}

\author{
R J Geraghty *,1, A Capes-Davis², J M Davis³ , J Downward ${ }^{4}$, R I Freshney ${ }^{5}$, I Knezevic ${ }^{6}$, R Lovell-Badge ${ }^{7}$, \\ J R W Masters ${ }^{8}$, J Meredith ${ }^{9}, \mathrm{G} N$ Stacey ${ }^{10}, \mathrm{P}$ Thraves $^{11}$ and M Vias ${ }^{1}$
}

${ }^{1}$ Cancer Research UK Cambridge Institute, University of Cambridge, Li Ka Shing Centre, Robinson Way, Cambridge CB2 ORE, UK; ${ }^{2}$ CellBank Australia, Children's Medical Research Institute, Locked Bag 23, Wentworthville, New South Wales 2145, Australia; ${ }^{3}$ School of Life and Medical Sciences, University of Hertfordshire, College Lane, Hatfield, Hertfordshire AL10 9AB, UK; ${ }^{4}$ Cancer Research UK, London Research Institute, 44 Lincoln's Inn Fields, London WC2A 3LY, UK; ${ }^{5}$ Institute for Cancer Sciences, University of Glasgow, 24 Greenwood Drive, Bearsden, Glasgow G61 2HA, UK; ${ }^{6}$ Department of Essential Medicines and Health Products, Quality, Safety and Standards Team, World Health Organization, 20 Avenue Appia, 1211 Geneva 27, Switzerland; ${ }^{7}$ MRC National Institute for Medical Research, The Ridgeway, Mill Hill, London NW7 1AA, UK; ${ }^{8}$ University College London, 67 Riding House Street, London W1W 7EJ, UK; ${ }^{9}$ Cancer Research UK, Angel Building, 407 St John Street, London EC1V 4AD, UK; ${ }^{10}$ National Institute for Biological Standards and Control, A Centre of the Medicines and Healthcare Products Regulatory Agency, Blanche Lane, South Mimms, Herts EN6 3QG, UK and ${ }^{11}$ Culture Collections, Public Health England, Porton Down, Salisbury SP4 OJG, UK

Cell-line misidentification and contamination with microorganisms, such as mycoplasma, together with instability, both genetic and phenotypic, are among the problems that continue to affect cell culture. Many of these problems are avoidable with the necessary foresight, and these Guidelines have been prepared to provide those new to the field and others engaged in teaching and instruction with the information necessary to increase their awareness of the problems and to enable them to deal with them effectively. The Guidelines cover areas such as development, acquisition, authentication, cryopreservation, transfer of cell lines between laboratories, microbial contamination, characterisation, instability and misidentification. Advice is also given on complying with current legal and ethical requirements when deriving cell lines from human and animal tissues, the selection and maintenance of equipment and how to deal with problems that may arise.

\section{INTRODUCTION}

Problems associated with cell culture, such as cell line misidentification, contamination with mycoplasma and genotypic and phenotypic instability, are frequently ignored by the research community. With depressing regularity, scientific data have to be retracted or modified because of misidentification of cell lines. Occult contamination with microorganisms (especially mycoplasma) and phenotypic drift due to serial transfer between laboratories are frequently encountered. Whatever the nature of the cell culture operation, large or small, academic or commercial, such problems can occur. The aim of these guidelines, updated from the previous edition of 1999, subsequently published in the British Journal of Cancer (UKCCCR, 2000), is to highlight these problems and provide recommendations as to how they may be identified, avoided or, where possible, eliminated.

Many countries now have legislation and Codes of Practice governing the use of human and animal tissue samples for research applications and these guidelines highlight the main legal and ethical issues that may be encountered.

The guidelines, prepared during 2013 by an ad hoc committee sponsored by Cancer Research UK, are meant to provide a series of pertinent and accessible reminders, which should be of benefit both to those for whom using cell lines is a new skill and those who may, despite years of experience, have allowed suboptimal procedures to become part of local practice. The guidelines are not meant to substitute for the many excellent textbooks that provide detailed information on many aspects of cell culture techniques and procedures. The guidelines are directed mainly at scientists in the UK but the principles will have international application.

Definitions of some terms frequently used in tissue culture are given in Box 1.

Any references to commercial products are given for information only and no product endorsement is intended or implied. 


\section{Abbreviations}

ACDP Advisory Committee on Dangerous Pathogens

ATMP Advanced Therapy Medicinal Product

ANSI American National Standards Institute

ATCC American Type Culture Collection

BSC Biological Safety Committee

BPE bovine pituitary extract

BSE bovine spongiform encephalopathy

BSI British Standards Institute

CITES Convention on International Trade in Endangered Species

CAT Committee for Advanced Therapies

CNS central nervous system

CNV copy number variation

$\mathrm{COSHH}$ Control of Substances Hazardous to Health

DAFF Department of Agriculture, Fisheries and Forestry

DDW double distilled water or distilled deionized water

DEFRA Department for Environment, Food and Rural Affairs

DMEM Dulbecco's modification of Eagle's medium

DMSO dimethyl sulphoxide

DSMZ Deutsche Sammlung von Mikroorganismen und Zellkulturen

EBV Epstein Barr Virus

ECACC European Collection of Cell Cultures

EMA European Medicines Agency

EU European Union

FDA Food and Drug Administration (USA)

GCCP Good Cell Culture Practice

GCP(L) Good Clinical Practice (Laboratory)

GLP Good Laboratory Practice

GMP Good Manufacturing Practice

h hours

hESC human embryonic stem cell

HFEA Human Fertilisation and Embryology Authority

HIV human immunodeficiency virus

HSE Health and Safety Executive

HTA Human Tissue Authority
HT Act Human Tissue Act

HTLV human T-cell leukaemia virus

IATA International Air Transport Association

$\mathrm{ICH}$

International Conference on Harmonisation of Technical Requirements for Registration of Pharmaceuticals for Human Use

IMP Investigational Medicinal Product

iPSC induced pluripotent stem cell

IRAS Integrated Research Application System

IUCN International Union for Conservation of Nature

IVF in vitro fertilisation

JCRB Japanese Collection of Research Bioresources

LIF leukemia inhibitory factor

$\mathrm{LN}_{2} \quad$ liquid nitrogen

MEF mouse embryo fibroblast

MHRA Medicines and Healthcare Products Regulatory Agency

MRC Medical Research Council

MSC microbiological safety cabinet

MTA material transfer agreement

NHS National Health Service

NRES National Research Ethics Service

PVDF polyvinylidene fluoride

QC quality control

REC research ethics committee

SIT selenium, insulin and transferrin

SOP standard operating procedure

SPF specific pathogen free

STR short tandem repeat

TPA tetradecanoylphorbol acetate

TOC total organic carbon

TSE transmissible spongiform encephalopathy

UKSCB UK Stem Cell Bank

UPW ultrapure water

WHO World Health Organization

\section{CELL LINE DEVELOPMENT, ACQUISITION AND AUTHENTICATION}

Section 1. Summary

- Record all data relevant to the origin of the tissue when starting a new cell line and keep tissue for DNA profiling

- Make sure the names of new cell lines are unique.

- Acquired cell lines should come from a reliable source and must be authenticated to avoid misidentification.

- Authenticated cells should be banked for future use and cultures replaced regularly from frozen stock.

- Regulations often apply to the distribution of cell lines and only authenticated stocks should be distributed.

Cell lines can be developed in-house, acquired from other laboratories (if there is no more reliable source) or purchased from a cell bank. Whatever the source, it is essential to ensure that the cells are authenticated and free from contamination such as mycoplasma.

\subsection{Developing a new cell line}

Deriving a new cell line, especially when human, from fresh tissue is an expensive and time-consuming exercise. The subsequent value of the new cell line will depend on the ability to authenticate its origin and on the associated information that is available.

\subsubsection{Tissue}

In addition to tissue taken for culture, if donor or patient consent and/or ethical review permit (see Section 2.1), it is recommended that additional material is stored for:

Confirmation of origin (authentication) (see Section 1.2.2). A small portion of the sample used for primary culture (or a blood sample or DNA derived from the donor) should be frozen or processed immediately. The tissue or DNA can then be used to demonstrate unequivocally that the cell line is derived from the putative donor. Short tandem repeat (STR) profiling is a recommended method for the purpose of authentication, although additional information on genotype (karyotype, copy number variation (CNV) mapping, or even whole-genome sequence) will sometimes help ensure identity.

Histopathological confirmation. A small portion of the sample being used to originate the culture should be fixed in formalin and used for histopathological assessment, ideally by the same histopathologist reporting the surgical specimen if this is from a patient. This step is particularly important if a patient sample is supplied to the laboratory directly by a clinician, because it may not be representative of the surgical specimen sent to the histopathologist. For instance, it may be taken at some distance from a tumour and consequently lack cancer cells, or it may be from a region that is unaffected by a specific pathology caused by a genetic or epigenetic defect. 


\section{Box 1 Definitions of terms frequently used in tissue culture}

Also refer to the studies by Schaeffer (1990) and Freshney (2010).

Anchorage dependence: the requirement for attachment in order for cells to proliferate.

Anchorage independence: the ability of cells to proliferate in suspension, either stirred or suspended in agar or Methocel.

Authentication: corroboration of the identity of a cell line with reference to its origin.

Cell cloning: see 'Cloning'.

Cell concentration: number of cells per $\mathrm{ml}$ of medium.

Cell density: number of cells per $\mathrm{cm}^{2}$ of growth surface.

Cell line: the progeny of a primary culture when it is subcultured. A cell line may be finite (qv) or continuous (qv).

Cell strains: cell lines that have been purified by physical separation, selection or cloning, and which have specific defined characteristics, for example, BHK-21-PyY, anchorage-independent cells cloned from the BHK-21 cell line following transformation with polyoma virus.

Cloning: the generation of a colony from a single cell; subculture of such a colony would give rise to a cell strain. Because of potential confusion with molecular cloning, this term is probably better modified to 'Cell cloning'.

Confluence: a cell density at which all cells are in contact with no remaining growth surface.

Contact inhibition: strictly, the loss of plasma membrane ruffling and cell motility on contact in confluent cultures, but often used to imply loss of cell proliferation after confluence, better referred to as 'Density limitation of cell proliferation'.

Continuous cell line: a cell line with an indefinite lifespan (immortal, over 100 population doublings; see also Immortalisation).

Density limitation of cell proliferation: the reduction or cessation of cell proliferation at high cell density.

Differentiation: acquisition of properties characteristic of the fully functional cell in vivo.

DNA profiling: the assay of hypervariable regions of satellite DNA, usually by determining the frequency of short tandem repeats in microsatellite DNA using PCR of individual loci with defined primers.

Established cell line: the use of this term is discouraged because it is ambiguous; the preferred term is continuous cell line (qv).

Explantation: isolation of tissue for maintenance in vitro.

Finite cell line: a cell line that survives for a fixed number of population doublings, usually $\sim 40-60$, before senescing and ceasing proliferation.

Generation number: the number of population doublings of a cell line since isolation.

Growth curve: a plot of cell number on a log scale against time on a linear scale.

Immortalisation: the indefinite extension of lifespan in culture, usually achieved by genetic modification, but already acquired by some cancer cells.

Passage: the event of subculture (qv), used to define the number of subcultures that a cell line has gone through since isolation. If used of continuous cell lines more usually the number of subcultures since last thawed from storage.

Primary culture: a culture from the time of isolation until its first subculture.

Primary explant: a small cellular fragment removed from tissue and placed in culture.

Provenance: details of the origin and life history of a cell line including various accidental and deliberate manipulations that may have a significant effect on its properties, latent or expressed.

Split ratio: the amount by which a culture is diluted before reseeding, usually a whole number.

Subculture: the transfer of cells from one culture vessel to another by dissociation from the substrate if a monolayer, or by dilution if grown in suspension.

Transformation: a heritable change involving an alteration in the genotype, usually subsequent to immortalisation. It is best reserved to describe an alteration in growth characteristics associated with malignancy (anchorage independence, loss of contact inhibition and density limitation of cell proliferation, and tumorigenesis in vivo).

Tumorigenesis: formation of a tumour in vivo, in the current context from implanted cells or tissue.

Normal tissue for comparison. A small quantity of blood (e.g., $10 \mathrm{ml}$ ) or normal tissue should be frozen. This tissue can later be used to look for genetic differences and could also be used for authentication. In the case of iPSC lines, or when direct reprogramming is used to derive one somatic cell type from another, it is also good practice to cryopreserve stocks of the original cells used. These could be important to derive additional cell lines using new reprogramming technology, but also to provide original donor material for validation of later discoveries made using the cell line. If somatic cell nuclear transfer (SCNT) or 'cloning' technology is used to derive cell lines, such as ES cells, then cells or tissue from both the somatic cell donor and oocyte donor should be kept in order to match nuclear and mitochondrial DNA, respectively.

\subsubsection{Clinical information}

If donor or patient consent and ethical reviews permit (see Section 2.1 and Box 2), as much of the following information as possible should be recorded and stored securely:

(1) Age and sex of donor/patient.

(2) Hospital and pathology numbers.

(3) Site of origin and nature of tissue specimen.

(4) Stage and grade of cancer or other syndrome, or pathology.

(5) Copy of histopathology report.
(6) Clinical history including treatment.

(7) Additional information such as tumour marker status, genetic information and family data etc.

(8) Evidence of informed consent and waiver of commercial rights by donor.

Information that could be used to unambiguously identify the donor - including name, hospital number, address and date of birth - should be stored with a higher level of security, preferably separate from other data. In the UK an NHS contract or honorary contract will be required to access patient details and such information should never be shared with unauthorised colleagues or released into the public domain.

\subsubsection{Accessory information}

The more information that is kept regarding the origin and derivation of the cell line, the more likely it is that the cell line will be useful for the originator and any subsequent users. New cell lines should be characterised to confirm their immortality, authenticity and tissue or cell type (Drexler and Matsuo, 1999).

It is recommended that a complete record of the culture details are kept at initiation or receipt and during all subsequent manipulations, particularly up to the point when the cell line is banked in liquid nitrogen $\left(\mathrm{LN}_{2}\right)$ (see Section 1.4.1). 
This should include the type, sources and batch numbers of all media and additives and the methods by which the cell line was established. It is helpful to record the split ratios and the passage number.

Although it may be necessary to use antibiotics in the primary culture, they should be removed as soon as possible and the cells tested for mycoplasma (see Section 4.2.4 and Table 3). The type of assay used for mycoplasma detection should be stated, as should the frequency and date of the last test.

Images of the primary culture, early passages and some later passages should be stored for publication and future reference.

If a cell line is genetically modified (including methods used to achieve immortality when relevant), it is essential to describe the process used, including details of sequences, mode of insertion and antibiotic resistance markers. Additional tests may be necessary to demonstrate lack of infectivity, for example, following transduction using lentiviral or retroviral vectors. For hybridomas, details of the sources of both sets of cells are needed. Where animal tissue is used to originate a culture, it is important to record the species and strain, age, sex and genetic status.

For iPSCs, or cell lines derived by direct reprogramming, the methods used should be described, including the genes and vectors used, whether these are integrating, inducible, episomal or excisable, or whether 'small molecule' chromatin-modifying drugs, shRNA, or other reprogramming methods have been included. This is necessary as the reprogramming method may affect the properties of the cells and may be important for comparisons with other cell lines.

\subsubsection{Cell line designation}

It is essential that the designation of the cell line is unambiguous, unique and maintains donor anonymity (Freshney, 2010). The format could be as follows: Institution - Source or series - code or log number - clone number; for example, MOG-G123-D4 (Medical Oncology Glasgow - Glioma Cell line 123 - clone D4). The full designation should be used in the materials section of publications. A similar scheme has been proposed for induced pluripotent stem cell (iPSC) lines (Luong et al, 2011).

If the cell line is obtained from another source, its original designation must be retained. If obtained from a cell bank, its accession number should be quoted in publications. Genetic modifications, sublines and clones should be indicated by a suffix, following the original designation. It is important that the designation is unique so that there is no ambiguity with other cell lines or biological resources during literature searches (a simple search in PubMed will confirm this).

\subsubsection{Publication}

The first publication should include the information described in the previous sections and subsequent publications should cite the first publication. Every publication should confirm that the cultures have been tested for mycoplasma (see Table 3 and Section 4.2.4) and that the test is negative. It is possible to eliminate at least some types of mycoplasma from cell lines, although this would only be worth attempting for particularly valuable or unique cells. The first publication should also provide evidence that the cells have been derived from the individual claimed to be the source, with subsequent publications comparing stocks of that cell line to the STR profile or other evidence cited within the first publication. Some journals insist on cell lines being made available as a condition of publication, so that other laboratories can repeat the work. Some funding agencies and institutions also encourage or insist that cell lines derived with their support are made available to others, free or at cost, even if they also require an MTA. Information on deposits in cell banks or whom to contact to obtain cells is helpful in this regard. Publication of work with the cell line implies its entry into the public domain and the right of others to acquire the cell line from the originator or the nominated cell bank.

\subsection{Acquiring a cell line from another laboratory}

Acquisition of cell lines presents a number of potential hazards; cell lines may simply not be what they are claimed to be and a published description of a cell line with a certain property is no guarantee that it is still the same line or has that same property. The more laboratories that a cell line has passed through since its origin, characterisation and contamination testing, the less reliance should be placed on its documented properties. However, even the originator as a source is not a guarantee of authenticity. If the receiving laboratory wishes to place any reliance on historic data obtained with a cell line, it should always carry out its own testing procedures (see Sections 1.2.2 and 1.5.1) before accepting an incoming cell line into general use. An enormous amount of time, cost and effort can be wasted by scientists using cell lines that are either misidentified or contaminated.

The cell bank or laboratory of origin should be able to provide a certificated DNA STR profile for human cell lines and evidence of authentication using an appropriate technique for non-human cell lines (see Sections 1.2.2 and 1.5.1). However, the publication of full STR profiles for human cell lines from tissue donated anonymously may present ethical problems. While profiles of long-established cell lines have been made widely available, the profiles of recently isolated cell lines could potentially be used to re-identify the donor or their family. Guidance on managing such scientific data is given in the study by Isasi et al (2012).

The name of the cell line should be checked against the International Cell Line Authentication Committee (ICLAC) database of misidentified cell lines (ICLAC, 2013a). The STR profile should be repeated at the time of banking the new cell line in $\mathrm{LN}_{2}$.

Human cell lines may carry pathogens, including viral contamination, representing a potential health hazard to laboratory workers (see Section 3.1). They may also become contaminated with bacteria, fungi, mycoplasma or viruses, which may spread to other cell lines. These contaminants may also be potential pathogens. If the cells are to be used in animals, whether as grafts of normal tissue or to derive tumours, or to make chimeras, it is also critical that they are tested and shown to be free of relevant pathogens, which might otherwise harm the animal colony or those who care for the animals. The cells or their derivatives may also be re-isolated from the animals for further study in vitro, in which case they need to be treated as a new sub-line and subject to further characterisation for genetic status as well as mycoplasma and other pathogens. Human cells passaged through animals could in theory have acquired replication-competent retroviruses from the animal host that could subsequently infect human cells, although the risk of this and of them being pathogenic to humans is very low.

In sourcing a cell line the establishment of provenance for that cell line should be a key requirement. This includes records of its origin and history, and quality control (QC) testing performed to ensure that it is free of contaminants (Freshney, 2002). Cell lines should only be obtained from sources where this provenance is clearly documented.

\subsubsection{Quarantine}

New cell lines should be quarantined in the laboratory and in storage until their origin has been authenticated (see Section 1.2.2) and they are shown to be free of microorganisms (see Section 4.2.4 and Table 3). Ideally, a separate quarantine laboratory should be available for this purpose. The next best approach is to have a 
Class II microbiological safety cabinet (MSC) and an incubator dedicated for quarantine. If this is not possible, other steps should be taken to minimise the risk of spreading contamination, including (a) cells in quarantine should be handled only after all other cell culture has been completed that day, (b) the new cultures should be placed in a dedicated incubator or into a sealed container before going into a general incubator, (c) the MSC should be cleaned after use with a suitable non-corrosive disinfectant (see Table 4) and run for at least another $5 \mathrm{~min}$ before shut down.

\subsubsection{Authentication}

On receipt and before freezing a master cell bank (MCB) or seed stock (see Section 1.4), cell line authentication should be performed using an approved DNA-based method (see Sections 1.2.2 and 1.5.1) for confirming the origin of a cell line (American National Standards Institute, 2011; ICLAC, 2013b) and to check for misidentification. Ideally, it will be possible to compare the DNA with that of the tissue or donor of origin (see Section 1.1.1), but unfortunately this is only possible in a minority of the cell lines already available. Nevertheless, it is desirable that a STR profile is defined before the cell line is used, so that at least it can be distinguished from other cell lines in the same laboratory and shown to be unique with reference to an international database (NCBI, 2013) or by contacting a reputable cell bank (see Table 1). It can then be tracked through subsequent transfers. For cell lines derived from inbred strains of mice, where STR profiles may not distinguish one line from another, but where a specific genetic alteration (mutation or transgene) has been introduced, a specific test for the allele in question should be established.

\subsubsection{Characterisation}

The user should also confirm that the cell line they obtain is fit for their own particular purpose. Even if a cell line is shown to be authentic, it may have lost a particular key characteristic with prolonged passaging. Karyotyping is a simple test that can reveal changes in a cell line. Indeed, it is routine to show that a line of ES cells or iPSCs has a normal karyotype if they are to be used for experiments involving production of chimeras and germ line transmission. Molecular assays to look for CNV or RNA profiling will also be indicative of changes, but are more costly. Nevertheless, a great deal of time and effort can be saved by confirming the appropriate characteristics before commencing work. It is also advisable to capture an image of the cell line in culture at different cell population densities and perform basic characterisation (e.g., calculating the population doubling time for that cell line) soon after arrival.
With newly developed cell lines it will also be important to confirm which type of cell the cell line is derived from using, for example, intermediate filament proteins, such as cytokeratins for epithelial cells, or specific cell surface markers, such as A2B5 for glial cells, and special properties required for the proposed study. More than one marker will be required for reliable characterisation.

\subsection{Cell banks}

A number of culture collections or cell banks have been established by either academic or commercial bodies (see Table 1). Cell lines from these sources are tested for identity and contaminating microorganisms that commonly occur in culture, so they are unlikely to be contaminated or misidentified, unless so stated in the accompanying literature. However, some of these cell lines have been acquired following multiple transfers between laboratories, so authenticity and freedom from microbial contamination are not guaranteed unless specifically stated in a Certificate of Analysis. The cell culture collections mentioned above routinely authenticate their cell line stocks and provide a Certificate of Analysis, including an STR profile, for each line they produce.

\subsection{Storage and banking}

Once a cell line has been developed or acquired and validated (i.e., shown to be authentic and uncontaminated) the first step to ensuring a reliable and reproducible supply of cells is the cryopreservation of about $201-\mathrm{ml}$ ampoules, each containing $1-5 \times 10^{6}$ cells. This will provide the vast majority of laboratories a ready supply for many years. Depending on the size and duration of the operation it is often useful to have a tiered system: (a) an MCB or seed stock, containing 10-20 ampoules, which should be protected and not distributed; (b) a distribution stock generated from the seed stock, which is used to provide the end users with cultures (Stacey and Doyle, 1997; Freshney, 2010) from which they will generate their own frozen stock. This user stock should contain sufficient ampoules to provide at least one ampoule for every 3 months of the proposed experimental period plus sufficient ampoules for contingencies; these cells should not be distributed other than to those within the group for whom they were frozen. Incorrect or serial banking (as occurs for cultures passed from one laboratory to another in a chain) results in a progressive increase in the population doubling number and additional risk of contamination or loss of key characteristics and to selection for abnormal growth characteristics accompanied by genetic and/or epigenetic changes.

Table 1. Cell culture banks

\begin{tabular}{|l|l|}
\hline Collection & Web site (web addresses accessed July 2014) \\
\hline American Type Culture Collection (ATCC) & www.atcc.org \\
\hline CellBank Australia & www.cellbankaustralia.com \\
\hline Coriell Cell Repository & http://ccr.coriell.org \\
\hline Deutsche Sammlung von Mikroorganismen und Zellkulturen (DSMZ) & www.dsmz.de \\
\hline European Collection of Animal Cell Cultures (ECACC) & www.phe-culturecollections.org.uk/ \\
\hline Health Science Research Resources Bank (HSRRB), Japan & www.jhsf.or.jp/English/index_e.html \\
\hline Japanese Collection of Research Bioresources (JCRB) & http://cellbank.nihs.go.jp \\
\hline NIH Stem Cell Unit & http://stemcells.nih.gov/research/nihresearch/scunit/ \\
\hline RIKEN Gene Bank & http://en.brc.riken.jp \\
\hline UK Stem Cell Bank (UKSCB) & www.ukstemcellbank.org.uk/ \\
\hline WiCell & www.wicell.org \\
\hline
\end{tabular}




\subsubsection{Cryopreservation}

Cell lines are preserved by freezing samples slowly (usually $1{ }^{\circ} \mathrm{C} \min ^{-1}$ ) in preservative (usually growth medium with $10 \%$ DMSO). An automatic controlled-rate cooling apparatus provides the most reproducible cryopreservation provided the freezing programme used has been optimised for that cell line's requirements but simpler devices may suffice (Freshney, 2010; Davis, 2011).

Certain cell types, for example, hESC, may require ultra-rapid freezing or vitrification (Hunt, 2011) where water is frozen in situ to form a glass and not allowed to permeate out of the cell as in slow freezing and is often used to freeze stem cells.

Every time a batch of cells is frozen down, it is recommended that one vial is resuscitated immediately to check viability. Vials removed from the bank should be thawed rapidly (by immersion in a water bath at $37^{\circ} \mathrm{C}$ ) and the cell suspension diluted gradually with pre-warmed medium.

\subsubsection{Storage}

Cell stocks should be kept below $-130{ }^{\circ} \mathrm{C}$ as viability may be progressively lost within a few months at $-80{ }^{\circ} \mathrm{C}$. Once at their final storage temperature it is also detrimental to warm them to $-80^{\circ} \mathrm{C}$ even for short periods. However, cells can be kept at $-80^{\circ} \mathrm{C}$ during the freezing process either for convenience, although usually for no more than a few days before being transferred to the definitive storage vessel, or when cells need to be kept frozen in multiwell dishes while waiting for results from a screen. This is commonly used during gene-targeting experiments with ES cells where it is necessary to screen many individual clones to find the relatively few that will be thawed for further growth and research. The multiwell dishes need to be thoroughly sealed so that they do not dry out at $-80^{\circ} \mathrm{C}$.

Potentially infectious material must be stored in the vapour phase of $\mathrm{LN}_{2}$ to reduce the risk of transfer of contaminating organisms (Tedder et al, 1995). It also eliminates the hazard of $\mathrm{LN}_{2}$-penetrating ampoules that may then explode on warming. Storage in vapour phase of $\mathrm{LN}_{2}$ is increasingly the norm for safety purposes but requires careful monitoring of the level of the $\mathrm{LN}_{2}$ as the smaller volumes used in vapour-phase storage will run out quicker.

For security, important material, (e.g., MCBs) should be divided into more than one storage vessel, preferably on different sites. Deposition and removal of frozen stocks should be recorded and controlled to avoid loss of entire stocks and to indicate when re-banking of stocks should be performed. Labelling of frozen stocks should be legible and resistant to $\mathrm{LN}_{2}$. It is recommended that the label on the frozen vial should contain the name of the cell line, batch number and freeze date as a minimum. These labels should be printed rather than handwritten, using labels that are suitable for prolonged storage in liquid nitrogen. Barcoding has proved to be a simple method that can contain most information on a small label.

The location of the vials should be detailed in a spreadsheet or database linked to details of the origin and characteristics of the cell line and the QC measures that have been applied to it.

Hazards associated with the use of $\mathrm{LN}_{2}$ include frostbite and cold burns, asphyxiation (i.e., oxygen depletion) and risk of infection and injury due to explosion of ampoules (see Section 3.1)

Cryostorage vessels should be fitted with alarms and storage temperatures checked regularly. It is recommended that levels of $\mathrm{LN}_{2}$ in the storage vessels are recorded at least once a week. Periodic audits for evidence of regular maintenance, monitoring and stock control will also help ensure safety and security of storage facilities.

\subsection{Cell line misidentification}

Misidentification occurs as a result of cross-contamination, poorly controlled manipulation or clerical error and implies a failure in good cell culture practice (GCCP); for example, accidental transfer of cells to a stock bottle of medium, having two cell lines in an MSC at the same time, mislabelling a flask or ampoule, or thawing the wrong ampoule. Other sources of cross-contamination are if feeder cells (e.g., as often used in ES cell culture) are still mitotically active due to inadequate irradiation or treatment with mitomycin $\mathrm{C}$, or if conditioned media is prepared without adequate filtration to remove cells. Whenever a rapidly growing, continuous cell line is maintained in a laboratory there is a risk that it may crosscontaminate (i.e., replace) other, more slowly growing lines. There is a long history of this problem, highlighted in the 1960s and 1970s (Gartler, 1967; Nelson-Rees and Flandermeyer, 1976; Nelson-Rees and Flandermeyer, 1977), but now often ignored. Few authors using cell lines such as KB, Int-407, WISH, Chang liver or Hep-2 acknowledge that they are in reality working with HeLa cells. Similarly, some cell lines with a variety of names and claimed tissues of origin are in fact MCF-7 (breast cancer) or T24 (bladder cancer) cells. Whatever the purpose of the experiments, it is essential to know the derivation of the cells. Even if the process being studied is not cell type-specific, others may cite the work in a context where it is.

Changes in cell behaviour or morphology may indicate cross-contamination and constant vigilance and attention to GCCP are essential (see Section 1.5.1).

A list of known misidentified cell lines is available from ICLAC (ICLAC, 2013a). However, even if a cell line is not on that list, a laboratory should always test to ensure that its own stocks of that cell line are authentic.

Simple precautions must be taken to minimise the possibility of misidentification, including:

(1) All culture vessels must be carefully and correctly labelled (including full name of cell line, passage number and date of transfer), as must storage containers.

(2) Only one cell line should be used in an MSC at any one time. After removal of the cells, the cabinet should be swabbed down with a suitable liquid disinfectant and run for a minimum of 5 min before the introduction of another cell line.

(3) Bottles or aliquots of medium should be dedicated for use with only one cell line.

(4) The formation of aerosols must be kept to a minimum.

(5) A return to frozen stocks should be made regularly (except where essential, never grow a cell line continuously for $>3$ months or 10 passages, whichever is the shorter period, unless otherwise validated).

\subsubsection{Recognising cell line misidentification}

Short tandem repeat profiling is the standard method for authenticating cell lines. An American Standard (ASN-0002 2011) provides information on how to use STR profiling for the authentication of human cell lines. Recommendations from the standard should be followed, including the use of at least eight core STR loci and application of match criteria ( $80 \%$ match threshold) to allow for a small amount of genetic drift in some cell lines. The standard can be purchased at the ANSI eStore (American National Standards Institute, 2011). Large numbers of organisations offer STR profiling of cell lines at a small cost.

For non-human cell lines, best practice will vary with the species being tested. As a minimum, it is recommended that non-human cell lines are tested for species specificity. Appropriate test methods include karyotyping (MacLeod and Drexler, 2005), isoenzyme analysis (Freshney, 2010) and mitochondrial DNA typing (DNA barcoding) (Cooper et al, 2007; O'Donoghue et al, 2011). It is also 
possible to compare partial sequences with the full genomic sequences that now exist for a number of human cell lines, including cancer cells, and for several inbred mouse lines and other commonly used species from which cell lines have been derived. A valuable resource is the Ensembl sequence database, a joint project between the European Molecular Biology Laboratory and the Wellcome Trust Sanger Institute (Birney, 2004).

\subsection{Cell line distribution}

\subsubsection{Introduction}

Transferring a cell line between laboratories may involve transport within a city, country or between continents. Therefore, consideration will have to be given to the condition of the cells, the means of transport and the legal requirements (see Section 2.1.7). Cell lines may be transported either as growing cultures or as vials of frozen cells.

Within the UK and European Union, use of a courier service should ensure delivery within $48 \mathrm{~h}$ to most destinations. Delivery to most places outside of the European Union should be possible within $96 \mathrm{~h}$ and this is compatible with sending growing cultures. However, it is impossible to guarantee that packages have remained under appropriate conditions (e.g., temperature, vibration-free) throughout the transport period. If frozen vials are sent, the fact that the refrigerant remains within the package on receipt should be sufficient to ensure that transport conditions have been acceptable.

Some couriers will not accept boxes containing solid carbon dioxide or $\mathrm{LN}_{2}$ for transportation; therefore, a specialist courier may need to be appointed.

\subsubsection{Transport containers}

Cultures of adherent cells growing in flasks should be sent with the flask filled completely with medium at the correct $\mathrm{pH}$. Disadvantages of this procedure are that the flask is heavy; there is a considerable volume of medium to leak if the flask is broken and cultures may subsequently become infected because of medium around the neck and cap of the flask. An alternative method is to remove all except a few drops of medium from the flask, gas appropriately, and seal the flask. The small volume of medium is sufficient to keep the cells moist but insufficient to allow frothing to occur and cells can remain viable for at least $72 \mathrm{~h}$ if kept cool.

For suspension cultures or cells that grow as floating aggregates, 2-ml plastic freezing vials are suitable containers for transport. Cells in medium should be transferred to the vial in a volume of $1.0-1.5 \mathrm{ml}$ and medium then added drop-by-drop to fill the vial before replacing the screw cap. Because of their size, such vials can be sent in small padded envelopes if suitably sealed in a plastic bag or secondary container containing sufficient absorbent material to soak up the medium in the event of a breakage or leak.

Insulated boxes suitable for transport of frozen vials of cells are used by various laboratory supply companies for distribution of frozen reagents. Such boxes typically have 5 - $\mathrm{cm}$-thick walls with a central cavity of $15 \times 15 \times 15 \mathrm{~cm}$. This can be filled with solid $\mathrm{CO}_{2}$, which will maintain temperature for a maximum of 4 days. Always have a vent for boxes holding solid carbon dioxide to allow gas to escape and make sure that the vials of cells are well sealed or in a gas-tight container to avoid $\mathrm{CO}_{2}$ gas entering, because this can significantly lower the $\mathrm{pH}$ of the medium. Use appropriate signage on the outside of the package, for example, UN1840 for dry ice ( solid $\mathrm{CO}_{2}$ ).

An alternative that is more expensive to buy and use, but which is very reliable, and increasingly used to send valuable samples, such as frozen embryos, is a Dry Shipper. These are specially designed Dewar's for liquid nitrogen, but where this is contained within a cryo-absorbant material. There is therefore no risk of spillage and cell vials (or straws) are kept frozen in the vapour phase at stable temperatures below $-150{ }^{\circ} \mathrm{C}$ for up to 10 days, depending on the size, capacity and make of the dry shipper. It is recommended to use makes and models that conform to IATA shipping regulations.

\subsubsection{Practicalities}

Experience dictates that adherence to the following points will increase the probability of successful transfer:

(1) Communicate fully with the carrier and the recipient in advance. Ensure that they both know the collection time and the anticipated delivery time. Exchange contact details in case problems arise. Keep shipping reference numbers such as Airway Bill Numbers and share them with the receiver of the package in case of delays or misrouting.

(2) Inform the recipient of what type of containers are being sent and the state of the cells and provide details of what to do with the cells when they arrive, to ensure that they have the correct medium available and that they are familiar with the growth characteristics of the cells.

(3) Ask the recipient to notify you when the cells arrive or when the cells have failed to arrive within a reasonable period.

(4) Send packages on a Monday to improve the chance of a weekday delivery.

(5) Ask the recipient to establish, as a high priority, their own frozen stock of the cells so that repeated transport is not needed.

\subsection{Regulations for the transport of cells}

Various regulations must be complied with when sending cells to other laboratories. These include legal requirements of various countries and regulations established by individual carriers. It is strongly recommended that full details of these are obtained before any transport is attempted. Regulations concerning the transport of potentially dangerous goods are published by the International Air Transport Association (IATA, 2013) and updated annually. There may also be issues of consent, with respect to use, distribution and export from specific countries, and the relevant documentation may be required by research funders and by journals.

In the case of human ESC lines there are special non-statutory regulations required under Medical Research Council (MRC) funding. These require that projects using hESC lines or their import, export or movement from one centre to another must have the approval of a national oversight body, the Steering Committee for the UK Stem Cell Bank (UKSCB) and for the Use of Stem Cell Lines (MRC, 2013).

It is beyond the scope of these Guidelines to spell out in detail the full regulations. However, the following points may be useful in providing general guidance:

\subsubsection{Within the UK}

Use an approved National Carrier or Courier service.

\subsubsection{Import to the UK}

While there are few restrictions on the movement of cell cultures within the European Union, importation of certain animal cells from other countries into the UK requires a permit from the Department for Environment, Food and Rural Affairs (DEFRA, 2013). This is particularly important for cells from agricultural species, including poultry, where there is a serious risk of importing non-endemic viruses.

Some countries are concerned about export of indigenous genetic resources, which could encompass tissues and cell lines, and may have imposed restrictions on export for any type of research, but especially for potentially commercial applications. 


\subsubsection{Export from the UK}

Apart from the USA and Australia, few countries have specific regulations regarding the import of cell lines and hence sending cells abroad should not present major problems. However, if material is classified as Advisory Committee on Dangerous Pathogens category 2 or above (ACDP, 2004), special conditions apply and the sender must undergo formal training. It is recommended that the cell line(s) are sent by courier service and that the contents of the package must be clearly labelled on the 'shipper's declaration' as 'biological material for research purposes'. Include the contact details of the sender on the outside of the package in case of mishap/accident and check with the receiving laboratory and the courier so you know what is required before you proceed.

An application should be made for a Veterinary Permit from the US Department of Agriculture (USDA, 2012) before shipment for the importation of cell lines or their products into the United States and to the Department of Agriculture, Fisheries and Forestry (DAFF, 2013) for Australia. A copy of the permit should be taped to the outside of the package.

For some countries, it is not just the cell line that is relevant but also whether the medium contains serum and its source. Use of a serum replacement or serum-free medium can provide a simple solution.

\section{DERIVATION OF A NEW CELL LINE}

Section 2. Summary

- There are ethical and legal requirements for obtaining tissue for cell lines.

- Specific regulations apply to the use of human tissue for research purposes.

- Patient consent is usually required for the use of human tissue samples and ownership must be defined.

- Separate regulations may apply to initiating cell lines from animal tissues.

- Transfer of cell lines from one laboratory to another may require a material-transfer agreement (MTA).

It is not the purpose of this document to describe the methodology for developing primary cultures and deriving cell lines from them, because extensive literature is already available. However, there are specific precautions and procedures that those proposing to do this type of work should be aware of.

\subsection{UK legal and ethical requirements}

These may be summarised as follows:

(1) Research involving human tissue samples will require ethical approval. To this end the Human Tissue Act 2004 legislates on the use of human tissue samples for a number of scheduled purposes including research. Informed patient consent may be required to store and use human tissue samples for research purposes and a Human Tissue Authority licence may be required to store human tissue samples for research purposes. Once a human cell line is established it is no longer covered by the Act.

(2) Any patient data where the patient name is recorded should be managed under the Caldicott Principles. These require the laboratory to have a Caldicott Guardian to assure compliance with these guidelines (Caldicott, 2013).

(3) The Human Fertilisation and Embryology Act 1990 (amended 2008) legislates on research using early human embryos up to 14 days of development or the first signs of primitive streak formation and is regulated and licensed by the Human Fertilisation and Embryology Authority (HFEA). The HFEA is not concerned with tissues from later-stage embryos or foetuses (e.g., from ectopic pregnancies or terminations) (HFEA, 2008).

(4) Clinical trials of cell-based medicinal products are regulated by the Medicines and Healthcare Products Regulatory Agency in compliance with the Medicines for Human Use (Clinical Trials) Regulations 2004 (MHRA, 2004a).

(5) An MTA should accompany all transfers of created cell lines between organisations and should define specific details including ownership, intellectual property rights and patent rights.

(6) The use of animals in experiments and testing is regulated under the Animals (Scientific Procedures) Act 1986 (ASPA). ASPA has now been revised to transpose European Directive $2010 / 63 / \mathrm{EU}$ on the protection of animals used for scientific purposes (EU Directives, 2010) and the revised legislation came into force on 1 January 2013. ASPA is not directly relevant to the derivation of a cell line from an animal that has been killed (by a schedule 1 method). However, it is relevant if any regulated procedure is required, such as tissue biopsy of a live animal, administration of substances, or derivation of a genetically altered animal. It is also relevant if cells are to be introduced into a live-born animal or animal embryo. While for most experiments it will make little difference with respect to regulation under ASPA whether the cells are of animal or human origin, some involving the latter may be considered contentious, especially if they concern the reproductive system or have the potential to lead to human characteristics developing in an animal (see Academy of Medical Sciences Report on Animals Containing Human Material (www.acmedsci.ac.uk)). New regulations and guidance on this type of research are being introduced and such experiments will be considered by the new Animals in Science Committee of the Home Office.

In the United States, information on human issues is available through the Presidential Commission for the Study of Bioethical Issues (PCSBI, 2013) and the Office of Human Research Protections (OHRP, 2011). Information on animal usage in the USA is available through the Office of Laboratory Animal Welfare (OLAW, 2013).

\subsubsection{Ethical approval for the use of human tissue in research}

All research projects, studies and clinical trials conducted in the UK involving National Health Service (NHS) patients, human tissue samples and identifiable clinical data must be favourably reviewed by a recognised NHS Research Ethics Committee (REC) before they can proceed. The principal aim of the REC is to safeguard the rights, safety, dignity and well-being of individuals participating in research (see Box 2). These RECs are managed and administered through the National Research Ethics Service (NRES, 2013), which is part of the NHS Health Research Authority (NHS, 2013). All applications for ethical review by a REC must be made through the electronic Integrated Research Application System (IRAS, 2013). In addition most NHS Trusts and Universities will have their own Research and Development Departments, which will approve all proposed new research, involving human tissue samples, before submission for ethical approval and scientists should make themselves familiar with their host organisation's local rules and policies. 


\section{Box 2 Patient consent form: points to consider}

1. Patient consent should only be taken by suitably qualified individuals with the required specialist training and researchers (other than those with medical qualifications) should not typically have any direct contact with donors.

2. The Patient Consent Form and associated Patient Information Sheet (necessary for most studies) should be written in concise and explicit language that anyone can easily understand, explaining clearly the need for the specimen, the overall objective of the research and why it is important (in lay terms).

3. The additional discomfort or inconvenience that will occur if the donor agrees to the request should be clearly explained.

4. The donor should be told clearly that there is no obligation whatsoever to participate in the research.

5. If the research may be exploited commercially, the donor should be told clearly what financial benefit might be gained from the research and a waiver to commercial rights should be requested.

6. The donor should be told that the research has been approved by the local Ethics Committee (give date and reference).

7. All forms should be marked Confidential.

8. It should be made clear that confidentiality will be assured, but if not (e.g., familial studies) indicate who will have access to the clinical data and how access will be controlled.

9. Fully informed consent means that the person should have access to all information relating to the use of the specimen provided. The details may be covered in a Patient Information Sheet.

10. The information sheet and consent form must be printed on official-headed notepaper.

11. Consent forms should address the following questions:

a. Have you read the information sheet about this study?

b. Have you had an opportunity to ask questions and discuss the study?

c. Have you received satisfactory answers to all your questions?

d. Have you received enough information about this study?

e. Which doctor have you spoken to about this study?

f. Do you understand that you are free to withdraw from this study (i) at any time, (ii) without giving a reason and (iii) without affecting your future medical care?

\subsubsection{The Human Tissue Act 2004}

The Human Tissue Act 2004 (HT Act, 2004) came into force on 1st September 2006, covers England, Wales and Northern Ireland and established the Human Tissue Authority (HTA) to regulate activities concerning the removal, storage, use and disposal of human tissue samples for a number of defined Scheduled Purposes, including 'research in connection with disorders, or the functioning of, the human body'. The HTA also licenses a number of activities including removal of relevant material from a deceased person and storage of relevant material for a Scheduled Purpose. Consent is the fundamental principle of the legislation. Different consent requirements apply when dealing with tissue from the deceased and the living. Scotland has separate legislation, the Human Tissue (Scotland) Act, 2006. Both acts are broadly similar in principle, but the Scottish legislation is based on authorisation rather than consent (Human Tissue (Scotland) Act, 2006).

\subsubsection{Human cell lines and the Human Tissue Act 2004}

The HT Act defines human tissue ('relevant material') as material that consists of, or includes, human cells. This includes blood, tissues and organs but does not include:

(1) Material that contains no cells, for example, serum, plasma and urine (providing the urine is acellular).

(2) Gametes (ova and sperm).

(3) Material created outside of the body in vitro, for example, embryos and cell lines.

Therefore primary human tissue and cells (i.e., those removed directly from a person) are defined as relevant material under the HT Act. Cell lines derived from expansion of primary cell cultures in vitro are not relevant material, as all of the original cells will have divided and so the cell line has been created outside of the human body. The storage of cell lines created from primary human tissue, for research purposes, does not require an HTA licence and the use of such cell lines is not covered by the HT Act or regulated by the HTA. However obtaining, retention and storage of any of the primary material from which the cell line was derived will be subject to the HT Act and HTA regulation, as will any cell lines derived with the intention of use in human therapy under the HTA (2007).
Under the HT Act consent is not required to store and use human tissue for research (including the creation of cell lines) if:

(1) The tissue sample was obtained before 1 September 2006.

(2) The tissue sample is from a living person and the proposed work is part of a research project or study approved by an NHS REC and the identity of the donor remains unknown to the researcher.

Under the HT Act a licence is not required to store human tissue for research if:

(1) The tissue sample is being held for use in an ethically approved research project or study, or where approval is pending.

(2) The tissue sample is being stored before transfer elsewhere, provided it is held for no longer than 1 week.

(3) The tissue sample is being held while it is processed with the intention to extract components that are not relevant material and provided the processing does not take longer than 1 week.

The HTA has published a series of Codes of Practice that provide full guidance and lay down the standards expected for each of the Scheduled Purposes, in order to comply with the HT Act (HTA, 2013). All scientists working in the UK who are producing cell lines from primary human material, for research purposes, should make themselves familiar with Codes 1 (Consent), 9 (Research) and 5 (Disposal).

\subsubsection{Research using human embryonic stem cells}

The Human Fertilisation and Embryology Act 1990 created the HFEA as an independent regulator of in vitro fertilisation (IVF) and human embryo research. One of the statutory functions of the HFEA is to license and monitor establishments undertaking human embryo research and this will include production of human embryonic stem cell (hESC) lines.

The original Act defined 5 purposes for which a research licence could be issued by the HFEA:

(1) Promoting advances in the treatment of infertility.

(2) Increasing knowledge about the causes of congenital disease.

(3) Increasing knowledge about the causes of miscarriages.

(4) Developing more effective techniques for contraception. 
(5) Developing methods for detecting the presence of gene or chromosome abnormalities in embryos before implantation.

Although these purposes did not preclude the derivation of human ESC, the reasons for doing so would have been limited by them. The Act had been passed before human ESC had first been derived, and there had been several other scientific advances, notably SCNT or cloning, which suggested that it needed updating. The Human Fertilisation and Embryology (Research Purposes) Regulations 2001 added three further purposes:

(1) Increasing knowledge about the development of embryos.

(2) Increasing knowledge about serious disease.

(3) Enabling any such knowledge to be applied in developing treatments for serious disease (HFEA, 2001).

The current version of the Act, passed in 2008, incorporates a number of very significant amendments, which were again made to accommodate rapid advances in science as well as changes in public attitudes and clinical practice (Lovell-Badge, 2008). These amendments included provisions for research on 'human admixed embryos', including human embryos that have been altered by the introduction of one or more animal cells. This would include the generation of chimeras with human ESC or iPSC.

The HFEA has published a Code of Practice (HFEA, 2013) that has a detailed section on Research and Training and lists all mandatory requirements for extraction, freezing, storage and use of human embryos, which are relevant to hESC research. In summary the HFEA can grant research licences for up to 3 years for individual, peer-reviewed research projects. All licence applications and renewals are evaluated by an HFEA Research Licence Committee. All new applications for a research licence must also have ethics approval (see Section 2.1.1). The HFEA charge an administration fee for granting and renewing project licences, which varies depending on the nature of the research. A requirement of the HFEA granting a research licence is that any cell lines produced must be deposited with the UKSCB (UKSCB, 2013). All uses of hESC lines are subject to non-statutory regulation overseen by the Steering Committee for the UKSCB, which approves new research on hESC lines including their import, export and transfer between institutions. It also approves deposit and release of hESC lines for the UKSCB.

In response to the Human Fertilisation and Embryology (Research Purposes) Regulations 2001 (HFEA, 2001) the UK's MRC was required to put into place the Steering Committee for the UK Stem Cell Bank and for the Use of Stem Cell Lines. This committee oversees and approves the import, export, transfer and use of hESC lines within the UK and has also published a Code of Practice for the Use of Human Stem Cell Lines (2010) available via the MRC (MRC, 2013).

Even though they are similar in properties and potential, human iPSC lines do not have to be deposited in the UKSCB, nor does the Steering Committee oversee their use. However, as with any other cell line, their use in a clinical setting would be regulated as described below.

\subsubsection{The use of human cell lines as therapeutic agents}

Research involving hESCs and other human tissue-derived cell lines will involve different regulatory authorities at different stages. For example, cell-based products that involve the destruction of a human embryo in their formation are initially licensed by the HFEA. Once an embryo has been disaggregated it is no longer subject to HFEA regulation. If the cells replicating from such a disaggregated embryo are intended for application on humans, they are then subject to the HTA (2007) up to the point of the first representative cell bank for that cell line. These regulations are administered by the HTA. However, hESC lines derived purely for research are not subject to this regulation. If the research project is to develop and manufacture a cell-based therapeutic product, then using the primary cells will remain under HTA regulation until the Medicines and Healthcare Products Regulatory Agency (MHRA) classifies the product as an Investigational Medicinal Product (IMP) or an Advanced Therapy Medicinal Product (ATMP).

In the UK clinical trials authorisation of all medicinal products is solely granted by the MHRA in compliance with the Medicines for Human Use (Clinical Trials) Regulations 2004 (MHRA, 2004a), which implement the EU Clinical Trials Directive 2001/20/EC (MHRA, 2004b). Favourable opinion from a recognised research ethics committee is also required for any clinical trial of a medicinal product (see Section 2.1.1). Full details of how to conduct a clinical trial of a medicinal product can be found on the MHRA website (MHRA, 2013).

Most human cell-based medicinal products intended for cell therapy or tissue engineering purposes will be classified as ATMPs. If these products are for the EU market then the European Medicines Agency (EMA), Committee for Advanced Therapies (CAT) (EMA, 2013), is responsible for preparing draft opinion on the quality, safety and efficacy of each ATMP for which a marketing authorisation is submitted. If opinion is favourable the MHRA will be responsible, in the UK, for authorising the clinical trial, inspecting the trial and issuing a manufacturing licence.

The UK National Institute for Health Research (NIHR) has produced a very useful online toolkit (NIHR, 2013). This provides practical advice and information on best practice and current legal requirements for conducting clinical trials in the UK. Similarly, the UK Department of Health and MRC have produced a UK Stem Cell Tool Kit (MRC, 2009) as an online regulatory tool for those conducting human stem cell research in the UK.

\subsubsection{Ownership and patent rights}

There are many who might lay claim to the ownership of specimens and their derivatives, including the donor and relatives, the surgeon and pathologists, the hospital authority where the sample was taken, the scientists engaged in the research, the institution where the research work was performed, the funding body and any collaborating commercial companies. The ultimate control of ownership, intellectual property rights and patent rights will need to be negotiated by the various interested parties. Most universities and research institutes will have a research office that deals with such negotiations, as do most of the larger funding agencies.

\subsubsection{Material-transfer agreements}

An MTA is a legally binding contract governing the transfer of research materials between two organisations where the recipient intends to use the materials for his or her own research purposes. Biological materials including reagents, cell lines, plasmids and vectors are the most frequently transferred materials and the MTA will define the rights of the provider and recipient with respect to the materials and any derivatives. This should include details of ownership, intellectual property rights and patent rights. The MTA should be signed by the legal representative of both the provider and recipient before any materials are transferred. If primary human tissue or cells are involved the MTA should include a statement confirming that ethical approval and informed consent have been obtained and the recipient should confirm that, on receipt, they will become responsible for using, storing and tracking the material in full compliance with the HT Act. The provider may also wish to state that no liability can be accepted for any problem arising from the use of the cells or tissue and that no guarantee of freedom from microbial contamination can be given.

Restrictions on the use of transferred cell lines should be minimal, but it is reasonable to insist on acknowledgement and 
even co-authorship where the originating laboratory has made a substantial contribution to the subsequent work. However, merely supplying a cell line would not in itself normally warrant co-authorship of any paper describing work carried out using that cell line. The MTA should also indicate that the cells must not be passed on to a third party or used for commercial exploitation. If the recipient derives a sub-line by cloning and/or genetic manipulation, then a new agreement of ownership will need to be established and this proviso should also be contained in the MTA. Again most universities and research institutes will have a research office that deals with agreeing and issuing MTAs, and will usually arrange for them to be signed by a legal representative.

\subsubsection{Creating cell lines from animal tissues}

In the UK the use of animals for research purposes is regulated by the Home Office and must comply with the Animals (Scientific Procedures) Act (Home Office, 2012) 1986 as amended in 2012. These amendments transpose European Directive 2010/63/EU (EU Directives, 2010) on the protection of animals used for scientific purposes. Scientists wishing to create cell lines from animal tissues must comply with current legislation. All institutions using animals for scientific procedures will have an Animal Welfare and Ethical Review Body (as defined by European Directive 2010/63/EU) (EU Directives, 2010) and specific approval from this committee may be required if obtaining animal tissues for the creation of cell lines. Further information can be found in the Guidelines for the welfare and use of animals in cancer research (Workman et al, 2010).

\subsection{Confirmation of origin}

If a new cell line is successfully developed it will be important to confirm the individual and cell type of origin. This will require authentication (see Section 1.2.2) and some degree of characterisation (see Section 1.2.3).

\subsection{Preservation}

Once a new cell line is established it becomes an important resource. Its authenticity, characteristics and provenance should be recorded (see Section 3.5.1), and cells should be frozen as soon as a sufficient amount is available (see Section 1.4).

\section{CELL LINE PRACTICE}

\section{Section 3. Summary}

- Ensure that you are familiar with local Safety Rules as established by the institution's Biological Safety Officer or advisor.

- Handle human tissue samples as potentially infectious material.

- Establish correct disposal routes for all types of laboratory waste before starting a procedure.

- Ensure that members of staff receive adequate training.

- Purchase media and reagents (especially serum) from reputable sources.

- Keep media preparation entirely separate from procedures involving living cells.

- Record all batch numbers of reagents and media.

- Establish 'standard operating procedures' (SOP) for all routine laboratory procedures.

- Ensure that all items of laboratory equipment (cabinets, incubators, autoclaves, water filtration units, etc.) are properly serviced and are working within prescribed limits.

- Inspect the cells under an inverted phase microscope before use. For routine culture, inspect cells daily and consult reference photographs of each cell line at different cell densities. Get to know the cells and how they behave under different conditions.

- Freeze new cell lines at the lowest passage possible after clearing quarantine. If they need to be frozen before being cleared they should be treated as if they were contaminated.

Detailed information is available on methodology and GCCP (e.g., Coecke et al, 2005; Freshney, 2010; Davis, 2011).

\subsection{Safety}

The guidelines on operator safety in cell culture presented here are meant primarily for private and academic research laboratories to be used in conjunction with local and national safety regulations and do not replace rules on safety within individual laboratories, as these vary according to local circumstances. The advice of the local Biological Safety Officer should be sought where there is any doubt about the introduction of new materials or procedures.

Employers are responsible for employee safety under the Health and Safety at Work Regulations (HSE, 1974) by providing information, instruction and training and effective protection against hazard in the workplace. The most relevant component is the Control of Substances Hazardous to Health regulations (COSHH, 2013). These regulations foster safe working practices by establishing that any proposed procedure is both justifiable and safe by requiring that a risk assessment is made before work is started. The COSSH regulations also set out a duty for employees to collaborate fully so that employers can meet the legal obligations. The risk assessment should be approved by the local authorised Biological Safety Officer or advisor (HSE, 1999). It should deal with the entire process and not just individual hazardous chemicals and biological agents. Risk assessments should not be copied from one laboratory to another since the same hazards represent different risks according to local conditions and the scale of the operation.

With regard to product safety, cell culture in the commercial sector is subject to strict regulation. For example, where cell culture products are to be used by the pharmaceutical industry, good manufacturing practice (GMP) (MHRA, 2007) must be complied with, along with the more specific guidance contained in a number of other documents issued by the European Union (EU) (EMA, 2007), the US Food and Drug Administration (FDA, 2010), the World Health Organisation (WHO, 2013) and the International Conference on Harmonisation of Technical Requirements for Registration of Pharmaceuticals for Human Use (ICH, 2013).

\subsubsection{Liquid nitrogen}

Possibly the greatest hazard encountered in the cell culture laboratory derives from $\mathrm{LN}_{2}$, which is used extensively in the freezing and long-term storage of cells and can injure by causing cold burns and frostbite or kill by asphyxiation or by the explosion of poorly designed $\mathrm{LN}_{2}$ containers. A worker at a laboratory in Edinburgh died from asphyxiation by $\mathrm{LN}_{2}$ evaporation-induced oxygen depletion in 2000 (BBC News, 2000) and there was a similar case in Australia in 2007 (Finkel, 2007), and a factory in 
Japan was destroyed by the explosion of a storage vessel in 1992 (HSE, 1992). Thus it is essential that all appropriate safety measures for the handling and storage of $\mathrm{LN}_{2}$, as identified in the relevant risk assessment, are in place in all laboratories and that these are rigorously adhered to; $\mathrm{LN}_{2}$ suppliers are a useful source of information and the latest regulations. Ultimately, however, local factors may be of critical importance (e.g., room locations and sizes, alarm and air-handling systems) and these MUST be factored into the risk assessment. The storage area should be well ventilated and there should be an oxygen deficiency alarm and mechanical ventilation (preferably activated through the oxygen monitor).

A further hazard associated with $\mathrm{LN}_{2}$ is the risk of explosion where vials are stored submerged in $\mathrm{LN}_{2}$. This problem was at its most acute when glass ampoules were widely used, but it still exists with poorly sealed plastic ampoules where $\mathrm{LN}_{2}$ is drawn into the vial during storage and causes a potentially dangerous explosion when the vial is warmed at thawing. Ideally, vials should not be submerged in $\mathrm{LN}_{2}$, but if they are, a protective wrapping such as Cryoflex (Nunc, Thermo Scientific) may be considered.

Appropriate personal protective equipment (e.g., insulated gloves, boots, waterproof apron and face masks) and equipment for safe manual handling of nitrogen vessels should be available. Staff should also receive training in safe working practices for the $\mathrm{LN}_{2}$ storage facility. Access to storage vessels should be strictly controlled.

\subsubsection{Biohazards}

The main hazard arising from cell cultures themselves is from infectious agents carried either by the cells or from the components of the culture medium. Cells can carry viruses and at least one fatality due to a viral infection acquired from cells has been reported (Hummeler et al, 1959). Sera could also contain a variety of microorganisms, including viruses and mycoplasma.

The biohazard risks associated with cell culture can be minimised by GCCP and appropriate containment and disposal protocols. Laboratory workers should also use personal protective equipment such as a lab-coat, gown or coveralls. Gloves and suitable eye protection are also recommended, depending on the task and the level of risk.

The use of blood or tissue from laboratory staff for the development of cell lines is not recommended, particularly for the generation of transformed cell lines, as the person concerned would have no immunity to the transformed cells.

\subsubsection{Clinical specimens}

Testing of the donor cannot be used as proof of absence of infection of the cell line, as contamination may occur by various sources in cell culture, and tests based on a blood sample taken before the cells were donated may not reflect the actual microbiological status of the donated tissue. Comprehensive advice on working with potentially infectious material in the laboratory is contained in guidelines from the Health and Safety Executive (ACDP, 2005). Material with a high potential risk of infection should be excluded or handled appropriately. All samples of blood, body fluids, secretions, tissues and cells are potentially infectious and must be handled at Containment Level 2 in a Class II MSC. Risk of exposure to infection can be minimised by avoiding the use of 'sharps' (such as needles and blades) and any items or processes likely to create aerosols. After taking blood, the needle should be removed from the syringe, not resheathed, and discarded safely into a 'sharps' container, before the specimen is transferred. You may wish to consider whether vaccination, for example, hepatitis B and tetanus, should be considered for laboratory workers handling human or animal tissue.

\subsubsection{Primary cultures and finite cell lines}

It is best to treat all cell lines as potential sources of infectious agents and handle accordingly; therefore, the above precautions should be maintained with any cell lines derived from clinical samples. There are documented cases of serious laboratoryacquired infections (e.g., hantavirus, lymphocytic choriomeningitis virus) from tissue, primary cell cultures and tumour cells taken from, or transplanted into, rodents (Lloyd and Jones, 1984). When obtaining primary tissue from laboratory animals it is important to ensure that the animals used are free of specific pathogens (SPF) and suppliers should provide evidence of testing. Alternatively, if the animals have been infected deliberately as part of an experiment, or are otherwise suspected of carrying a specific pathogen, tissues obtained from them must be handled appropriately, including the relevant level of containment. This information should be used in risk assessments and cross-referenced in laboratory record books where the respective primary cells are used. It should be assumed that any hazards associated with primary cultures will also be present in cell lines derived from them.

\subsubsection{Stem cell lines}

In principle, the infectious hazards that may arise with stem cell lines are no different from any others in that workers should consider the likelihood of contamination with pathogens associated with the species and tissue of origin. In the case of hESCs the risk of contamination of the original donor tissue with the most serious blood-borne pathogens is very low (Zou et al, 2004). However, when stem cell lines are differentiated to form tissue cell types they may provide a suitable culture substrate for the growth of pathogenic viruses such as HCV, HBV (Si-Tayeb et al, 2012) and other pathogens depending on the cell types generated (Bandi and Akkina, 2008). Thus, when planning experiments to provide a particular differentiated cell type, consideration should be given to the most likely contaminants that may arise in reagents, cells and any test samples that might replicate in the differentiated cell types. Human iPSCs can be isolated from a broad range of tissues; therefore, the risk is associated with the tissue.

Human and mouse feeder cell lines used to grow stem cells may also carry viruses and can present similar risks to those for continuous and finite cell lines (see Section 3.1.6). In addition, where primary mouse embryo fibroblasts (MEFs) are used to culture stem cells a range of viruses may occur in the original colony, so a viral screen should be obtained for the MEFs and mycoplasma testing performed (see Section 4.2.4 and Table 3).

\subsubsection{Continuous cell lines}

The extensive safe use of continuous cell lines indicates that there is little risk from routine cell culture. However, as most cell lines are not fully characterised, they should be subjected to local risk assessment by the local Biological Safety Committee (BSC). A tumour grew in a laboratory worker accidentally inoculated with cells of a human tumour cell line through a needle (Gugel and Sanders, 1986) and cancers have been transferred between people during transplantation (Stephens et al, 2000). Although the growth of tumour cells from a different person is unlikely in healthy individuals, anyone with a compromised immune system is at greater risk.

\subsubsection{Genetically modified cells}

The introduction of genes can reactivate dormant infectious agents in the host cell or create new agents by recombination. Viral vectors that can infect human cells (e.g., amphotropic retroviruses) are particularly dangerous. Recommended procedures for creation, use, storage, transportation and disposal of genetically modified organisms, including modified cell lines, are given in the Genetically Modified Organisms 
(GMOs) (Contained Use) Regulations, UK, 2000 and its subsequent amendments (HSE, 2000) ( $n b$ : these do not apply to construction of somatic cell hybrids). These regulations describe how to make a full risk assessment, which must receive approval from the Local Genetic Modification Safety Committee and, in certain cases, specific approval from the HSE may be required.

Genetically modified cells may require special conditions. For example, selective pressure may need to be maintained on transfectants to retain the genetic modification and the pressure may need to be maintained during storage. Distribution of genetically modified cells may be subject to regulation, depending on the modification.

\subsubsection{Containment}

The HSE guidance on what level of containment is required for working with potentially infectious material, including human tissue samples states: 'Laboratories that work with potentially infectious material, but where it is unlikely that group 3 or 4 agents are present should achieve Containment Level 2 as minimum' (HSE, 2005). Long-established continuous cell lines may be handled at Level 1, subject to the approval of the BSC, but in practice it may prove to be more convenient for all tissue culture facilities to be maintained at the same level, that is, Level 2. This level of containment is also applicable to untested cell products such as monoclonal antibody-containing supernates and cell homogenates. These HSE guidelines also recommend that all subculture, or other procedures involving the manipulation of bulk cells, should be performed in a Class II MSC. Laminar flow devices other than MSCs should not be used for cell culture. Horizontal flow cabinets, where the airflow is directed at the operator, are particularly hazardous and must never be used when working with cells that are known to, or may, carry pathogens, or with potentially infectious cell derivatives. Horizontal laminar flow cabinets are still used by laboratories working with early embryos and ES cells that are known to be pathogen-free. However, the use of this type of cabinet should be strictly controlled and subject to local risk assessment and approval by the local safety committee. Modifying MSCs and other contained cell culture hoods, for use with microscopes, may disrupt airflow so much that they are neither safe for the operator nor provide adequate protection for the cell cultures. Such modifications should only be made following approval by the local safety committee and any modified equipment should always be re-validated before use.

The spread of infection often occurs via contaminated aerosols and any process that produces aerosols from crude cell culture preparations is a potential source of infection. Such processes (e.g., centrifugation, tissue disaggregation, vortex mixing and sonication) should be contained or the material rendered harmless before it is processed. There are special guidelines for the safe use of flow cytometers with unfixed cells (Schmid et al, 2007a, b).

Any cell samples to be submitted for specialist microscopy services (e.g., confocal microscopy or scanning/transmission electron microscopy), or other external services should first be discussed with the responsible microscopist and Biological Safety Officer or advisor and should be subject to appropriate risk assessment.

Detailed information on cell culture laboratory design, use of MSCs and GCCP is widely available (Coecke et al, 2005; Freshney, 2010; Davis, 2011).

\subsubsection{Disposal}

Control of the disposal of laboratory waste should prevent exposure of staff and environment to infectious hazards and prevent contamination. In the UK those producing clinical waste (including drugs, pharmaceuticals, animal and human material and any items contaminated with these materials) have a duty in law to ensure its safe disposal (Environmental Protection Act, 1990). All infected waste arising from work in laboratories should be made safe to handle by appropriate means (e.g., autoclaving), before disposal by incineration. England and Wales, Scotland and Northern Ireland each have their own hazardous waste legislation in the form of statutory instruments and rules to implement the EU Directive on Waste, which sets out a framework within the Member States for controlling the production, transport and disposal of hazardous waste (Hazardous waste, 2004-2009).

\subsection{Training}

New staff should not be allowed to work in the tissue culture facility until deemed competent. Both practical, hands-on training and theoretical training should reinforce the need to use good aseptic technique and awareness of contamination as an important issue that can be minimised through GCCP. Practical training is best carried out on a one-to-one basis with an experienced member of staff, with extensive reference made to any relevant SOP. As compliance with any demanding technique tends to decrease with time and familiarity, performance should continue to be monitored.

Individuals experienced in cell culture starting in a new laboratory should read the protocols specific to the laboratory, such as routine handling and monitoring of cell cultures (see Sections 3.5 and 4), safety, waste disposal, autoclaving, incubator use/sharing, labelling of cultures and medium storage.

\subsection{Culture reagents}

It is recommended that reagents and sera are purchased from suppliers who issue certificates of analysis or results of QC testing with each batch of product. Buy in bulk quantities suitable for the level of usage to minimise batch variation and store at the temperature recommended by the manufacturer. Aliquot proteinaceous solutions, such as serum and trypsin, rather than repeatedly freeze and thaw large bottles.

\subsubsection{Media production}

Most commercial suppliers offer a custom media service for specialised formulations. Basic media formulations are usually offered both as single strength and as $10 \times$ concentrated liquids by suppliers. Although cost savings can be achieved by using $10 \times$ concentrates, discounts are often available on large orders of $1 \times$ medium and therefore many laboratories have adopted its use. If concentrate is used, this is diluted into bottles containing sterile ultra-pure water. Sterile L-glutamine and sodium bicarbonate are then added and finally the $\mathrm{pH}$ is adjusted. The advantage of this system is that it is quick and technically undemanding. However, several points should be borne in mind.

(1) Media concentrates have changes made to their basic formulations, mainly to overcome problems of solubility.

(2) Precipitate is often seen on storage. If the concentrate is aliquoted the precipitate can cause variation between bottles.

(3) Suppliers acidify the medium to improve solubility. This in turn requires significant amounts of base to neutralise the medium.

\subsubsection{Powdered media}

Powdered media produce more stable uniform products with longer shelf lives than concentrates. However, the process does require specialised equipment for filtration and bottling. Note:

(1) The powder should be free flowing and white to off-white in colour, with no sign of dampness.

(2) The medium should be stirred until all the powder is dissolved. The presence of fine particulate matter may require pre-filtration or a change of supplier. 
(3) Medium should always be prepared and filtered on the same day.

Sterilisation requires filtration to a pore size of $0.22 \mu \mathrm{m}$. Cellulose filters are most common but polyvinylidene fluoride (PVDF) filters should be used when protein is present in the medium. Although a $0.22-\mu \mathrm{m}$ filter will prevent the passage of bacteria and fungi, mycoplasma can pass through pores of $>0.1 \mu \mathrm{m}$ in diameter; therefore, most commercial suppliers now filter to this limit. However, it is still advisable to screen regularly for mycoplasma contamination rather than assume its absence from media. It is difficult to exclude viral contamination and pre-screening of natural products, such as serum, by the supplier is usually the only option.

Single-use disposable cartridges or filter flasks are recommended as the most convenient option for media filtration. Note:

(1) The equipment should be dedicated for media production only.

(2) A Class II MSC should be dedicated to media and supplement production (horizontal laminar flow may be used provided there are no antibiotics or toxins in the medium). If a dedicated cabinet is not possible, then it should not have been used for cell culture for at least 1 hour. It must also be cleared of all equipment and thoroughly cleaned with $70 \%$ alcohol or non-corrosive disinfectant.

(3) All tubing should be clean and autoclaved before use and connections should be securely in place.

(4) Sterile bottles and caps should be stacked outside the cabinet and introduced one at a time to receive medium. Stacking bottles within the flow cabinet will seriously compromise the airflow and consequently sterility.

(5) During bottling, representative samples should be drawn off at regular intervals. These samples should then be incubated at $37^{\circ} \mathrm{C}$ for at least 10 days to check for contamination.

(6) Bottled media should be stored at $4{ }^{\circ} \mathrm{C}$ in the dark.

(7) Some medium components such as glutamine are heat labile (Ozturk and Palsson, 1990). Glutamine degradation occurs at $\sim 3 \%$ per month when stored at $2-8{ }^{\circ} \mathrm{C}$, but the rate of degradation increases if the medium is warmed to $37^{\circ} \mathrm{C}$. This is best addressed by adding glutamine when the bottle is first used and by discarding bottles after a set time period (e.g., 1 month). Stabilised forms of glutamine are available that avoid this problem (e.g., Glutamax, Invitrogen).

(8) If any sample shows contamination in repeated samples, the whole batch of medium should be discarded.

\subsubsection{Serum batch testing}

Simple preliminary tests can help avoid the disastrous consequences of using media, sera or supplements that do not adequately support cell growth. Many laboratories buy large batches of serum (held in store by the supplier) to avoid batch variability; batches can be kept at $-80^{\circ} \mathrm{C}$ without noticeable loss of function. Batch testing of serum should use a relevant range of cell lines and may include criteria for (a) cell attachment and spreading, (b) cloning efficiency, (c) growth rates and, where appropriate, (d) a functional assay and/or colony morphology. Low serum concentrations (e.g., 1\%) can help highlight differences between sera. It is important to limit carry-over of the old serum during testing, as this could mask differences between the old and new batches. Trypsinisation of adherent cells will usually remove most of the serum, but cells growing in suspension will need to be centrifuged. The selected batch may be held on reserve for a maximum of 1 year and delivered as required.

\subsubsection{Defined media and serum replacements}

Developing a defined medium, that is, serum-free and preferably free of all impure or undefined products, for a particular cell line or cell type can be very time consuming. There is a wide range of serum-free media available (see Box 3), although not all of these are totally defined. Any protein supplementation should be with recombinant protein. The advantages of defined media include standardisation, reproducibility, absence of microbiological contaminants and the potential for selective culture of specific cell types. However, they are generally more expensive and will mean that one medium may not suffice for all cell lines in use. Alternatively, a regular medium such as DMEM or DMEM/F12 may be supplemented with a serum replacement (see Section 6.6). Some of these, for example, SIT (Sigma) are defined (selenium, insulin and transferrin), but others are proprietary mixtures and undefined and should be batch-tested as for serum. Fully defined or at least serum-free medium should be used whenever possible.

\section{Box 3 Suppliers of serum-free media or serum substitutes}

It should be noted that many of these formulations will contain protein supplements, such as bovine pituitary extract (BPE), which are undefined. Defined supplements that are available include selenium, recombinant insulin (Sigma, Invitrogen) and recombinant transferrin (Merck Millipore: www.millipore.com) as well as many peptide growth factors (Abbiotec: www.abbiotec.com, and others) and albumin (Novozymes-Biopharma: www.biopharma.novozymes.com).

\section{Serum-free media}

AthenaES: www.athenaes.com/

Atlanta Biologicals: http://atlantabio.com

BD Biosciences: www.bdbiosciences.com/

Cell Applications: www.cellapplications.com

CellGenix: www.cellgenix.com

CellGro: www.cellgro.com

Clonagen: www.clonagen.com

CoaChrom: www.coachrom.com/

Hyclone (GE Life Sciences): https://promo.gelifesciences.com/gi/hyclone

Hycor: www.hycorbiomedical.com

Invitrogen: www.invitrogen.com

Irvine: www.irvinesci.com

Lonza (Clonetics, BioWhittaker): www.lonza.com

Mediatech: www.cellgro.com

Metachem: www.metachem.co.uk

Millipore (Merck Millipore): www.millipore.com/

MP Biomedicals: www.mpbio.com/

PeproTech: www.peprotech.com

Perkin Elmer: www.PerkinElmer.co.uk

PromoCell: www.promocell.com/

Roche Applied Science: www.roche-applied-science.com/

Sigma (JRH Biosciences): www.sigmaaldrich.com

Stem Cell Technologies: www.stemcell.com

Stratech: www.stratech.co.uk

TCS CellWorks: www.tcscellworkscatalogue.co.uk/

Zen Biologicals: www.zen-bio.com

\section{Serum substitutes}

Bayer: www.bayer.com

Celox: www.celoxmedical.com/

Invitrogen: www.invitrogen.com

Irvine: www.irvinesci.com

Lonza: www.lonza.com/

Metachem: www.metachem.co.uk

MP Biomedicals: www.mpbio.com/

Protide: www.protidepharma.com/

Roche Applied science: www.roche-applied-science.com/

Sigma: www.sigmaaldrich.com

Web addresses last accessed July 2014. 
Table 2. Comparison of fumigants used for decontaminating MSCs

\begin{tabular}{|c|c|c|c|}
\hline Property & Formaldehyde Gas $\left(\mathrm{CH}_{2} \mathrm{O}\right)$ & Hydrogen peroxide vapor $\left(\mathrm{VHP} ; \mathrm{H}_{2} \mathrm{O}_{2}\right)$ & Chlorine dioxide gas ${ }^{3}\left(\mathrm{ClO}_{2}\right)$ \\
\hline Toxic & $\begin{array}{l}\text { Yes (by inhalation, skin contact } \\
\text { and ingestion) }\end{array}$ & Yes (skin and eye irritant) & $\begin{array}{l}\text { Yes (by inhalation, also skin, eye } \\
\text { and mucous membrane irritant) }\end{array}$ \\
\hline Carcinogenic & Yes & No & No \\
\hline $\begin{array}{l}\text { Long term exposure limit }{ }^{1} \\
\text { (p.p.m.) }\end{array}$ & 2.0 & 1.0 & 0.1 \\
\hline $\begin{array}{l}\text { Short term exposure limit }{ }^{1} \\
\text { (p.p.m.) }\end{array}$ & 2.0 & 2.0 & 0.3 \\
\hline Corrosive & No & $\begin{array}{l}\text { Yes (with nylon, cellulose, copper, } \\
\text { lead, iron oxide, epoxy) }\end{array}$ & Yes (if chlorine gas is present) \\
\hline Sealing of MSC & Air tight seal required & Air tight seal not required & Air tight seal required \\
\hline $\begin{array}{l}\text { Access to lab during } \\
\text { fumigation of MSCs }\end{array}$ & Not permitted due to leakage danger & Permitted & $\begin{array}{l}\text { Not permitted due to leakage } \\
\text { danger }\end{array}$ \\
\hline Penetration of HEPA filters & Yes & Not a true gas so may not penetrate HEPA filter & Yes \\
\hline Humidity requirement $(\mathrm{RH})$ & Above $60 \%$ & $30 \%\left(\right.$ Steris $\left.^{2}\right)$, ambient (Bioquell ${ }^{2}$ ) & Above $60 \%$ \\
\hline Residue & $\begin{array}{l}\text { Yes (paraformaldehyde and } \\
\text { methenamine-requires extensive cleaning) }\end{array}$ & No & Minimal $(\mathrm{NaCl})$ \\
\hline $\begin{array}{l}\text { Approximate decontamination } \\
\text { time per cabinet (hours) }\end{array}$ & $11-17$ & $3-10$ & $3-4$ \\
\hline Relative cost & Cheap (no specialist equipment required) & More expensive (specialist equipment required) & $\begin{array}{l}\text { More expensive (specialist } \\
\text { equipment required) }\end{array}$ \\
\hline Advantages & $\begin{array}{l}\text { Cheap } \\
\text { Non-corrosive } \\
\text { Current industry standard method }\end{array}$ & $\begin{array}{l}\text { Safe by-products and no residue } \\
\text { Relatively fast } \\
\text { Automated }\end{array}$ & $\begin{array}{l}\text { Safe by-products and minimal } \\
\text { residue } \\
\text { Best sporicide }\end{array}$ \\
\hline Disadvantages & $\begin{array}{l}\text { Slow with added clean up time due to } \\
\text { residue formation } \\
\text { Carcinogen }\end{array}$ & $\begin{array}{l}\text { Some corrosion issues } \\
\text { Vapour may not penetrate HEPA filters } \\
\text { Instability of VHP }\end{array}$ & $\begin{array}{l}\text { Highly toxic } \\
\text { Some corrosion issues with } \\
\text { metals }\end{array}$ \\
\hline Overall effectiveness & Good & Good & Good (best sporicide) \\
\hline \multicolumn{4}{|c|}{$\begin{array}{l}\text { Notes: This table compares the three fumigants most commonly used in the laboratory to decontaminate MSCs (also refer to the studies by Czarneski and Lorcheim (2011) and HSE (2005b)). } \\
\text { MSSS that are being used for clean cell culture work will only need to be fumigated following any episodes of microbial contamination attributed to the cabinet and before changing filters, } \\
\text { servicing, moving or disposing of the cabinet, depending on local rules and risk assessment. Decontamination of MSCs using toxic fumigants is a potentially hazardous process and should only } \\
\text { be performed by fully trained members of staff using the appropriate personal protective equipment and following detailed Standard Operating Procedures and Risk Assessments. For those } \\
\text { laboratories not equipped to undertake fumigations several companies that supply MSCs also offer a contract fumigation service. }{ }^{1} \text { Long- and short-term exposure limits as defined by the UK } \\
\text { Health and Safety Executive (2005). }{ }^{2} \text { Steris (www.steris.com) and Bioquel (www.bioquell.com) are two commonly used commercial suppliers of hydrogen peroxide generators and associated } \\
\text { equipment required for VHP fumigation. MSCs must be fitted with the correct ports. }{ }^{3} \mathrm{Chlorine} \text { dioxide fumigation requires a chlorine dioxide generator and associated equipment available } \\
\text { from several companies in the UK including SafeOx (www.safeox.com) and Activ-Ox (www.activox.org). MSCs must be fitted with the correct ports. }\end{array}$} \\
\hline
\end{tabular}

\subsection{Equipment}

\subsubsection{Microbiological safety cabinets}

Most cell culture is undertaken in a Class II MSC. These cabinets provide protection to the operator as defined in the BS EN 12469:2000 (British Standards Institute, 2000) and protect the external environment while maintaining a clean working environment, but give no protection against toxic, radioactive or corrosive materials for which specialised cabinets are required. The effectiveness of a MSC is dependent on its position, correct use and regular testing.

Cabinets should be sited away from doors, through traffic and air-conditioning inlets. Movement in the area of the MSC will disturb the airflow and therefore access to the area should be restricted to essential personnel. Recommendations for siting MSCs are given in BS5726:2005 (British Standards Institute, 2005).

All MSCs should be tested annually for airflow, operator protection factor and filter integrity. This should be increased to every 6 months where GMOs or primary unscreened human material are used (HSE, 2001). Cabinets used for general cell culture should be tested annually. Testing and servicing should be carried out by trained competent personnel. Before servicing and testing is carried out, adequate fumigation is required. This is usually performed using formaldehyde gas but some manufacturers offer vaporised hydrogen peroxide (VHP) sterilisation, which leaves no toxic residue (see Table 2). Advice should be sought from the local safety committee regarding whether this is acceptable in your institute. Training is essential before either procedure is carried out. An equipment safety certificate is normally required by servicing engineers before testing can begin.

When performing cell culture work within an MSC it is important to minimise the potential for contamination of the working environment and cross-contamination between cultures. This can be greatly assisted by the following:

(1) Swab down the inside of the cabinet and the work surface with $70 \%$ alcohol before starting.

(2) The inside of an MSC and items that you bring into it should be clean but are not sterile, and good aseptic technique requires that you do not touch any of the surfaces with sterile instruments, pipettes, and so on.

(3) Do not make rapid movements within the cabinet, as this may disrupt the airflow.

(4) Manipulate fluids slowly and gently with the assistance of a pipetting aid to avoid the creation of aerosols.

(5) Never have more than one cell line at a time in the cabinet.

(6) Do not overcrowd the cabinet and never obstruct the grills or front opening. 
(7) Organise the work area such that sterile reagents and cultures do not come in contact with each other.

(8) Use caution when homogenising tissues or cells in an MSC, If high-energy processes such as sonication are used the particles cannot always be assumed to be contained by the cabinet airflow.

(9) Clean and decontaminate the cabinet inner surfaces after each work session and periodically decontaminate the tray under the MSC working surface using $70 \%$ alcohol or a non-corrosive disinfectant.

(10) Some MSCs have an ultraviolet lamp installed to assist with disinfection of the cabinet. Although ultraviolet light can be useful, its effectiveness is limited and it should not replace other decontamination procedures.

(11) A Bunsen or similar burner must not be used when working in a MSC, (unless absolutely required for a specialised procedure) as they disrupt the airflow pattern, reducing the cabinet's effectiveness, and they pose a fire risk.

\subsubsection{Incubators}

Incubators are used during cell culture to maintain an optimal cell growth environment by controlling the temperature, humidity and carbon dioxide concentration. Most modern incubators are humidified and used with an atmosphere typically containing $5 \% \mathrm{CO}_{2}$, although other concentrations may be required depending on the bicarbonate concentration of the medium. The following points should be considered:

(1) Incubators should be chosen carefully with reference to their expected use and any desirable features that can be included within budget (see Box 4).

(2) Humidifying water can contain an antibacterial/antifungal agent or other appropriate contamination control measures (see Box 4), but only if checked beforehand for any possible toxic effects on the cultures (e.g., by performing a plating efficiency assay).

(3) Incubators should be calibrated for temperature and gas composition.

(4) $\mathrm{CO}_{2}$ levels should be checked monthly using a calibrated $\mathrm{CO}_{2}$ meter (marked deviations will be evident as a change in $\mathrm{pH}$ of the medium).

(5) Every 6-8 weeks the incubator should be emptied, dried and cleaned with $70 \%$ alcohol or equivalent non-corrosive disinfectant. All shelves should be similarly removed and cleaned.

(6) Individual trays on which culture flasks can be easily moved in and out of the incubator should be used to reduce contamination from spillages.

(7) Incubator temperatures and contents should be inspected daily.

(8) Spillages must be dealt with immediately.

(9) All infected plates, dishes or flasks must be removed immediately and disposed of appropriately.

(10) Incubators must only be used for cell culture and not for incubating microorganisms or biochemical samples.

(11) Gassed incubators should be attached to a suitable cylinder change over unit or protected central supply.

(12) Cylinders used to supply gas should be securely anchored.

(13) Cylinders should be clearly labelled and have the correct regulating valves attached. The tubing should be appropriate for the pressure of the gas used and securely fastened to avoid any leakage of carbon dioxide, which is a potential asphyxiant.

(14) A $0.22-\mu \mathrm{m}$ porosity, non-wettable filter should be used on the input gas lines.

(15) Cylinders should be changed by trained personnel wearing suitable high-impact eye and foot protection.

(16) It is preferable to have the $\mathrm{CO}_{2}$ supply cylinders or tank located outside the sterile area to minimise disturbance when changing or refilling.

\subsubsection{Hypoxic incubators}

Although atmospheric oxygen concentrations and those inside standard $5 \% \mathrm{CO}_{2}$ cell culture incubators are close to $21 \%$, in vivo concentrations are much lower, ranging from 1-12\%. The use of hypoxic incubators and chambers is becoming increasingly widespread in order to mimic in vivo conditions using in vitro cell culture models. In particular hypoxia-inducible factors have been shown to influence tumour cell metabolism, angiogenesis, growth and metastasis (Bertout et al, 2008). Hypoxic conditions have also been suggested to be important in maintaining pluripotency in hESC cultures (Lengner et al, 2010). Hypoxic cell culture is often performed using 'tri-gas' incubators where a nitrogen supply is used to displace and reduce oxygen levels within the incubator, typically to a range between 0.5 to $2 \%$. This type of incubator has the disadvantage that hypoxic conditions will be lost when the door is opened or when cell cultures are removed. To maintain stringent hypoxic conditions it will be necessary to use a specialist hypoxic chamber/workstation. These are sealed units that maintain the required hypoxic atmosphere and typically have sealed glove ports that allow cultures to be manipulated without removing them from the unit. They usually also have an air lock to allow media, reagents and consumables to be transferred into the unit without losing the hypoxic environment.

\subsubsection{Microscopes}

Most tissue culture rooms are equipped with an inverted light microscope that allows the user to inspect their cell cultures regularly and to perform cell counts (see Section 3.4.6). A suitable range of objective lenses would be $\times 4, \times 10$ and $\times 40$ with $\times 10$ eyepieces. Image contrast is enhanced using phase contrast optics. It is preferable to have a trinocular head to accommodate a digital camera. Cell images can be captured and stored to monitor any morphological changes that take place in the culture, an essential element of QC. Fluorescence microscopes are also commonly used in tissue culture labs where fluorescent labels have been introduced into the cells or the animals from which cell cultures are derived. These may require all or part of the lab to be light-free.

\subsubsection{Live-cell imaging}

Live-cell imaging can be defined as the study of living cells using images that have been acquired from microscopes or screening systems. It can be used for cell line QC and for the study of cellular dynamics. Real-time cell-imaging systems allow the user to monitor live-cell growth and any changes in morphology that could occur as a consequence of differences in cell density or culture conditions without intervention. They are less labour-intensive and can save money on plastics and media. However, the user must be aware of which parameter is being used to measure growth as this will influence kinetic analysis if growth rates are being calculated. Real-time cell-imaging systems have been developed by many companies and some examples include Incucyte (Essen), xCELLigence (Cambridge Bioscience), CellVivo (Olympus), Cell Observer (Zeiss), Cytation3 (BioTek Instruments), DeltaVision Elite (GE Healthcare), CloneSelect Imager (Molecular Devices) among others.

The advent of high-content analysis (HCA), in which cell images that have been captured using a high-resolution light microscope are extracted and quantitative data is analysed in an automated process, is having a great impact on research as multiple markers at subcellular resolution can be measured in large-scale quantitative assays. Examples of high-content systems include the Opera and Operetta (PerkinElmer), CellInsight NXT HCS Platform (Thermo Scientific), Cell-IQ (Chipman) and the multi-plate imaging system Biostation CT (Nikon). 


\section{Box $4 \quad \mathrm{CO}_{2}$ incubators}

\section{Choosing an incubator}

The following are desirable attributes of an incubator, unrelated to specific requirements, such as low temperature control or hypoxia. Many of these relate to cleaning the incubator and it must be emphasized that this is done regularly.

1. Interior corrosion-resistant, for example, stainless steel. Copper will give better control of fungal contamination but does tend to corrode. Copper alloy (antimicrobial copper) may be a suitable alternative but is expensive.

2. Smooth interior with no crevices; easy to access and clean.

3. Shelving/racking that can be removed completely for cleaning and sterilizing if necessary.

4. Dual temperature control with safety override.

5. Although some suppliers provide HEPA-filtered air circulation, non-fan-assisted incubators will reduce the airborne spread of contamination within the incubator and are generally preferable.

6. With modern design and insulation a water jacket is not required and makes the incubator difficult to move. It does, however, hold its temperature for a longer period if the power fails.

7. Large incubators should be avoided; it is better to have two or more smaller incubators. It makes cleaning easier and gives better back-up in the event of failure or contamination.

8. Vibration free, as vibration can cause non-random distribution of cells.

9. Humid atmosphere with $\mathrm{CO}_{2}$ controlled by non-corroding sensor, for example, gold wire or infra-red.

10. Data output ports to record temperature and $\mathrm{CO}_{2}$ fluctuations.

11. A cooled incubator should be used if it is to be located in a warm laboratory.

\section{Controlling contamination}

Microbial contamination in cell culture humidified $\mathrm{CO}_{2}$ incubators can be minimised by following a number of simple preventative steps including: (1) good aseptic technique; (2) using incubators with design features to reduce contamination (Section 3.4.2) having a regular cleaning strategy together with a periodic decontamination method.

\section{Aseptic technique}

1. Cell culture vessels are a major source of contamination and should be wiped with $70 \%$ alcohol before being placed in the incubator.

2. Where possible cell culture flasks with secure $0.22-\mu \mathrm{m}$ filter caps should be used in preference to loose-lidded dishes and plates, to prevent spills and aerosols of cell culture media that will allow microorganisms to grow.

Regular cleaning and maintenance

1. The shelves, inner and outer doors and door seals should be wiped down in situ with a suitable disinfectant cleaner followed by $70 \%$ alcohol, to remove any residue, once a week. Any visible spillages of medium should always be immediately removed.

2. Water in the humidity tray should be replaced weekly and the tray cleaned as above. Adding disinfectants or chemicals to the water in the incubator humidity tray is not recommended as many of these will produce volatile compounds, which may be cytotoxic to the cultured cells. Instead sterile distilled water should be used and replaced weekly. However, many laboratories do successfully use a number of chemical additives in their incubator humidity trays including copper sulphate $(1.0 \mathrm{~g}$ per litre) and a number of commercially available products containing mainly quaternary ammonium compounds such as Aqua Clean (www.cleantabs.co.uk), Clear Bath (www.spectrumlabs.com), SigmaClean (www.sigmaaldrich.com) and Aquaguard (www.promokine.info/products).

3. All air, $\mathrm{CO}_{2}$ and HEPA filters should be changed at the appropriate service intervals, and door seals and gaskets replaced if showing signs of wear.

\section{Suggested decontamination procedure}

1. Should be performed immediately if cell cultures are found to be contaminated and at regular weekly, monthly or quarterly intervals depending on the type of work being conducted.

2. Switch the incubator off.

3. Remove all metal shelving, brackets and supports from the incubator. Wash with a suitable detergent, allow to dry and then autoclave. Copper shelving is quite soft and may warp in the autoclave but can be wiped down with a suitable disinfectant followed by $70 \%$ alcohol rather than autoclaving.

4. Remove the humidity pan, if separate, discard the water and wash and disinfect the pan as above.

5. If the humidifying water sits in the bottom of the incubator, drain and then wipe down all internal surfaces with a suitable detergent. Allow to dry and then wipe down with a suitable disinfectant followed by $70 \%$ alcohol, making sure not to damage internal sensors or fans.

6. Remove the door seal, if possible, then clean and disinfect it as above.

7. Reassemble the incubator, switch on and allow it to reach working temperature and $\mathrm{CO}_{2}$ concentration before use.

8. Many of the $\mathrm{CO}_{2}$ incubators currently available have built-in automatic high temperature decontamination cycles, which will usually either be moist heat at $90^{\circ} \mathrm{C}$ or dry heat at $180^{\circ} \mathrm{C}$. These processes run overnight and aim to eliminate the need to remove and manually disinfect the incubator components. If available the decontamination cycle should be run immediately if any cell cultures are found to be contaminated. Be aware that if a fungal contaminant is present you will need to run two decontamination cycles with a 12-h gap. The first will kill any vegetative organisms and any resistant spores will then germinate and be killed in the second cycle. Automatic decontamination cycles can also be run as a preventative measure at weekly, monthly or quarterly intervals depending on the type of work being conducted.

\subsubsection{Cell counting}

Cell counting, manual or electronic, is essential to determine growth rates accurately and to set up reproducible experiments. Manual counting is usually performed using a hemocytometer (Improved Neubauer), which consists of an engraved glass microscope slide and thick coverslip creating a chamber where the cells are placed and then counted under a microscope. As the volume within the chamber is known the cell count per unit volume can be calculated. The hemocytometer is cheap and allows visual inspection of the cells, but cell counting is labour-intensive, particularly if many cell lines are used, and variable between users. Electronic counters are expensive but the reproducibility and speed that they provide are of importance when dealing with many cell lines, although they are prone to error, particularly if the cells are clumped.

\subsubsection{Autoclaves and sterilising ovens}

Autoclaves are used for sterilising equipment and consumables. Safe operation is described in the HSE guidelines (HSE, 2012) and some advice on correct function has been provided by the Centers 
for Disease Control (CDC, 2008). Autoclaves must be covered by insurance, which will necessitate an annual inspection. It is essential that proper protective clothing (including a face visor and heat-proof gloves) are used and the autoclave not opened until the temperature has fallen below $50{ }^{\circ} \mathrm{C}$. Autoclaving of liquids in glass containers can present particular hazards: autoclave bottles with the caps slack and set a limit on the volume autoclaved to give consistent sterilisation and to leave a standard volume after autoclaving. Leave autoclaved liquids to cool before moving off the autoclave tray or trolley, to reduce the risk of boilover from superheated liquids.

It is essential that regular checks are made to ensure that the autoclave is operating at the required temperature and pressure. Qualitative indicators (e.g., autoclave tape) are useful to distinguish items that have been autoclaved from those that have not, but they do not guarantee that the item is satisfactorily sterilised. Some indicators (e.g., Thermalog, Bennett Scientific) confirm that the minimum requirements of heat and humidity have been met for full sterilisation but must be located at the centre of the load (inside a replicate vessel if necessary). Autoclaving of a test sample (e.g., spore strip testing) may be necessary to confirm sterilisation when setting up a procedure for the first time.

\subsubsection{Water-purifying apparatus}

The use of ultra-pure water is essential for successful cell culture. Reverse osmosis followed by passage through mixed-bed ion-exchange resins and carbon and micropore filtration provides pyrogen-free water of tissue-culture grade. Water should be measured for $\mathrm{pH}$, conductance and total organic carbon (TOC) (Whitehead, 2007). Serum can protect cells from toxins and consequently the use of ultra-pure water is critical in low protein or serum-free conditions. The purity of water is only maintained if it is placed in suitably clean bottles dedicated to storage of water or media.

\subsection{Quality control, record keeping and research integrity}

\subsubsection{Records}

Details of all routine and experimental procedures should be recorded as they are generated. Good practice requires that records be dated, legible, clear in content and made in blue or black ink directly into a bound laboratory notebook or onto a standard form. Each piece of work must have an aim/objective, method, equipment used, results and conclusion and must be signed at the end of the record. Enough detail must be recorded to enable the work to be reproduced exactly. Standard operating procedures (SOPs; see below) should be referenced wherever possible. More stringent requirements may apply to work done under GLP, GMP or GCP(L) conditions.
Records of routine procedures carried out, such as cell counts, cell-line passaging and medium preparation can be kept on standard forms designed for the purpose. These should be stored in a dedicated file, which may be electronic and cross-referenced in experimental notebooks as required. The advent of tablet computers means that primary records may be electronic and linked to a central database, but some laboratories may insist on hard-copy lab books with numbered pages for primary records. If electronic notebooks are used, care should be taken to protect and back up records and to allow ongoing access regardless of changes to the software or hardware used. Procedures should be in place to validate the authorship, date and content of entries; this is particularly important if a patent or other commercial application may arise from experimental work.

The originals of all experimental records remain the property of the funding agency or laboratory and must be lodged with them when an experimenter leaves that laboratory or changes funding agencies. Such records should be securely archived, with systems in place to permit easy retrieval along with protection against tampering.

\subsubsection{Quality control}

A Certificate of Analysis should be requested from the supplier for each batch of material and this should be stored securely for future reference with the date received in the lab book or dedicated file.

Quality assurance of cultured cell lines, in terms of their authentication, stability and contamination are dealt with above (see Section 1).

\subsubsection{Standard operating procedures}

Procedures that are regularly performed in a standard manner are best documented in the form of an SOP. This is a clear and detailed list of instructions, written such that suitably trained individuals can understand and perform the task in the intended manner. It should include details of the equipment, reagents and techniques to be used, as well as methods for calculating and interpreting the results. Ideally, each laboratory or organisation should have its own system for the issue, tracking and review of SOPs. This should ensure that all copies can be tracked so that all scientists have the most recent versions and that they are reviewed on a regular basis (at least once every 2 years is suggested). All SOPs should be controlled by either a version number or a date. A nominated scientist should be responsible for the issue of all SOPs, such that only one approved version is current, reflecting best procedure and all other versions are removed from use. Ideally, the system should include provision for permanent archiving of all versions and revisions of all SOPs. Where the experimental nature of the work precludes strict adherence to the SOP it is important that the appropriate SOP is referenced and the deviations noted.

\section{CELL LINE PROBLEMS: IDENTIFICATION AND ELIMINATION}

\section{Section 4. Summary}

- Misidentification remains a major problem, so all cell lines should be obtained from a reliable source and shown to be authentic.

- Contamination with mycoplasma is still prevalent and requires good tissue culture practice and frequent testing to ensure that cell lines are clear of contamination.

- Other contaminations can largely be avoided by GCCP

- Antibiotics should not be used routinely.

- Decontamination should not be attempted unless the cell line is critical and irreplaceable and even then should only be attempted by an experienced laboratory.

- Cell lines, particularly continuous cell lines, are prone to genotypic and phenotypic instability requiring regular characterisation and replacement from cryopreserved stocks.

Cultures should always be examined under an inverted phase microscope before any manipulations are performed and frequent assessments should be made of the viability and appearance of the cell population with reference to photographic records. 


\subsection{Cell line misidentification}

One of the most serious and persistent problems is cell line misidentification often resulting from cross-contamination. This means that authentication is required on receipt, before storage and distribution, and after completion of a project (see Sections 1.2.2 and 1.5.1).

\subsection{Mycoplasma contamination}

Contamination of cell cultures with mycoplasma was first noted in the 1950s but is still regrettably often disregarded. The following important points should be noted:

(1) Mycoplasma contamination is very frequent, worldwide.

(2) Using mycoplasma-contaminated cells can result in erroneous, misleading or false experimental results.

(3) Owing to lack of visible signs mycoplasma-positive cell cultures can go unnoticed.

(4) Be aware of potential sources of mycoplasma contamination (see Section 4.2.2).

(5) Use good aseptic technique and laboratory practices to avoid mycoplasma contamination.

(6) Have an effective quarantine procedure for all untested cell lines.

(7) Establish a regular and continuous mycoplasma-testing programme.

(8) Scientific journals are starting to ask for evidence of mycoplasma testing before accepting papers for publication.

Mycoplasmas and the related Acholeplasmas (collectively referred to as 'mollicutes') are the smallest and simplest self-replicating bacteria and are significant in that they have become probably the most prevalent and serious microbial contaminant of cell culture systems used in research and industry today. Owing to the absence of any visible morphological changes or other symptoms mycoplasma infection of cell cultures often goes undetected. However, it is the invisible effects of the contamination on the infected cells that makes it such a serious problem. It is therefore essential that routine mycoplasma testing is performed regularly on all research cell lines to ensure the validity of study results before publication. Although $>20$ different species of mycoplasma have been isolated from cell cultures, $>95 \%$ of infections are caused by six prevalent species, which are the following: M. arginini, M. fermentans, M. hominis, M.hyorhinis, M. orale and Acholeplasma laidlawii.

Although primary cell cultures and early passages are less frequently contaminated with reported incidences of between 1 and 5\%; continuous cell lines have much higher incidences of between 15 to 35\% (Drexler and Uphoff, 2002).

Mycoplasma are unaffected by many of the antibiotics commonly used in cell culture, such as penicillin and can grow to extremely high titres (typically $1 \times 10^{7}$ to $1 \times 10^{8}$ organisms per $\mathrm{ml}$ ) in mammalian cell cultures without producing any turbidity in the medium, or other obvious symptoms. In addition mycoplasma are extremely small $(0.15-0.3 \mu \mathrm{m})$ and pleomorphic, and will pass through standard $0.22-\mu \mathrm{m}$ bacteriological filters $(0.1-\mu \mathrm{m}$ filters are required for sterilisation). The only assured way of detecting mycoplasma contamination is regular testing.

\subsubsection{Effects}

The effects of mycoplasma contamination on the host eukaryotic cell are quite variable but have been shown to alter many host cell functions including growth, morphology, metabolism, the genome and antigenicity (Drexler and Uphoff, 2002). Using mycoplasma-contaminated cultures in experiments will therefore clearly call into question the validity and significance of any research data generated and could result in the publication of erroneous experimental results. Research journals are now starting to ask for evidence that mycoplasma-free cell cultures are used in studies before accepting papers for publication. In addition the time and cost involved in cleaning contaminated laboratories, obtaining new cell cultures and repeating experiments is significant as is the potential reputational damage of publishing erroneous results.

\subsubsection{Sources}

Common sources of mycoplasma contamination in the laboratory include:

(1) Cross-contamination from other mycoplasma-positive cell cultures.

(2) Laboratory equipment and work surfaces.

(3) Laboratory personnel (often via respiratory tract infections).

(4) Cell culture media, sera and reagents.

(5) The liquid phase of $\mathrm{LN}_{2}$ cryostorage vessels.

(6) Feeder cell cultures.

(7) Laboratory animals

\subsubsection{Prevention}

The first step in avoiding mycoplasma contamination is being aware of the most common sources of infection, as outlined in the previous section and then to adopt working practices that reduce the risk of contamination from these sources. First and foremost is the importance of adopting proper aseptic cell culture technique (Coecke et al, 2005; Freshney, 2010). Failure to do so will result in equipment, work surfaces, media and reagents rapidly becoming contaminated and leading to the spread of infection. Routine regular cleaning of all MSCs and incubators, including the use of sterile water for humidification of incubators, will help minimise the risk of mycoplasma contamination.

Working with only one cell culture at a time and using dedicated, separate, media and reagents for each individual cell line will greatly reduce the risk of cross-contamination and spread of infection.

Having an effective quarantine procedure in place will also minimise the risk of introducing mycoplasma contamination into the laboratory. All cell lines of unknown mycoplasma status, in particular cell lines brought in from external laboratories and collaborators should initially be quarantined (see Section 1.2.1) until tested negative for mycoplasma. Only then should the cell cultures be transferred to the clean cell culture laboratory.

The overuse and reliance on antibiotics rather than good aseptic technique can result in higher mycoplasma contamination rates and mycoplasma are typically partially or completely resistant to the antibiotics commonly used in cell cultures such as penicillin and streptomycin.

\subsubsection{Detection}

There are four basic steps to any successful and reliable mycoplasma testing and detection programme.

(1) Test all actively growing cell lines at regular intervals.

(2) Only cell lines previously tested and confirmed as mycoplasma negative should be used in your clean cell culture lab. All non-tested cell lines must be quarantined until they are tested negative for mycoplasma.

(3) Test all continuously maintained cell cultures at defined regular intervals (typically monthly to quarterly, depending on individual risk assessment). Maintain these cultures, where possible, on a short-term basis (2-3 months only) before discarding them and replacing with fresh vials from the same tested working stocks. This strategy not only reduces the amount of testing required but also reduces the problem of culture evolution and genetic drift.

(4) Make sure all cell lines are mycoplasma tested before use in a clean cell culture room.

A large number of simple, reliable, sensitive and specific tests are now available to detect mycoplasma contamination in cell culture (see Table 3). When choosing a test method or a test kit, consider the sensitivity of the assay (usually recorded as colony-forming units per 
Table 3. Mycoplasma detection methods

(Also refer to the studies by Uphoff et al (1992) and Tuly and Razin (1996))

\begin{tabular}{|c|c|c|c|c|}
\hline Method & Sensitivity & Specificity & Advantages & Disadvantages \\
\hline $\begin{array}{l}\text { Microbiological culture } \\
\text { (selective broth and agar). }\end{array}$ & High & High & $\begin{array}{l}\text { European Pharmacopeia } \\
\text { recommended test. } \\
\text { Gives a definitive result. }\end{array}$ & $\begin{array}{l}\text { Requires specialist microbiology lab. } \\
\text { Relatively slow. } \\
\text { Potential source of cross-contamination. } \\
\text { Some strains are non-culturable. }\end{array}$ \\
\hline $\begin{array}{l}\text { Direct DNA stain, e.g. Hoechst } \\
33258 \text { or DAPI }\end{array}$ & Low & $\begin{array}{l}\text { Low (non-specific cytoplasmic } \\
\text { DNA stains) }\end{array}$ & $\begin{array}{l}\text { European Pharmacopeia } \\
\text { recommended test. } \\
\text { Rapid and cheap. }\end{array}$ & $\begin{array}{l}\text { Reading and interpretation of test can } \\
\text { be difficult and subjective. }\end{array}$ \\
\hline $\begin{array}{l}\text { Indirect DNA stain, (using } \\
\text { indicator cells e.g. } 3 T 3 \text { or } 3 T 6 \text { ) }\end{array}$ & High & $\begin{array}{l}\text { Low (non-specific cytoplasmic } \\
\text { DNA stains) }\end{array}$ & $\begin{array}{l}\text { Amplifies contaminant so easier } \\
\text { to interpret than direct stain. }\end{array}$ & $\begin{array}{l}\text { Indirect therefore slower and more time } \\
\text { consuming than direct stain. }\end{array}$ \\
\hline $\begin{array}{l}\text { PCR, e.g., Universal } \\
\text { Mycoplasma Kit }{ }^{1}, \text { Mycoplasma } \\
\text { Plus }^{2}, \text { MycoSensor }^{2} \text {. }\end{array}$ & High & $\begin{array}{l}\text { Medium (will not detect all } \\
\text { Mycoplasma species) }\end{array}$ & $\begin{array}{l}\text { Rapid and very sensitive. } \\
\text { Several good commercial kits } \\
\text { available. }\end{array}$ & $\begin{array}{l}\text { False positives due to carry over } \\
\text { contamination from positive controls } \\
\text { and samples. } \\
\text { False negatives due to PCR inhibitors in } \\
\text { sample. }\end{array}$ \\
\hline $\begin{array}{l}\text { Enzyme Linked Immunosorbant } \\
\text { Assay (ELISA), e.g. MycoProbe }{ }^{3} \text {, } \\
\text { Mycoplasma PCR ELISA }{ }^{4} \text {. }\end{array}$ & $\begin{array}{l}\text { Medium (High } \\
\text { if amplified } \\
\text { ELISA) }\end{array}$ & $\begin{array}{l}\text { Medium (will not detect all } \\
\text { Mycoplasma species) }\end{array}$ & $\begin{array}{l}\text { Rapid and cheap. } \\
\text { Useful and simple for screening } \\
\text { large numbers of samples. }\end{array}$ & $\begin{array}{l}\text { Amplified ELISAs have additional stages } \\
\text { and are slower. } \\
\text { Requires access to ELISA } \\
\text { spectrophotometer. }\end{array}$ \\
\hline $\begin{array}{l}\text { Biochemical Detection, } \\
\text { e.g. MycoAlert }{ }^{5} \text {. }\end{array}$ & Medium & High & $\begin{array}{l}\text { Very rapid. } \\
\text { Good for urgent testing of small } \\
\text { sample numbers. }\end{array}$ & Requires access to a luminometer. \\
\hline
\end{tabular}

$\mathrm{ml}$, or $\mathrm{ng} \mathrm{ml}^{-1}$ for PCR-based kits). The number of species detected is also important. Positive control samples may be kept where the appropriate microbiological expertise and proper quarantine facilities are available; otherwise it is better to avoid keeping infected material. For those laboratories not able or not wishing to perform their own mycoplasma testing there are commercial companies and organisations that offer a comprehensive mycoplasma-testing service including Mycoplasma Experience Ltd. (www.mycoplasma-exp.com) and the HPA Culture Collections - ECACC (www.phe-culture collections.org.uk).

\subsubsection{Eradication}

The first step is to autoclave, or disinfect, the contaminated culture and associated media and dispose of them. Next thoroughly clean and disinfect (Table 4) all hoods, incubators, centrifuges, refrigerators, microscope stages and any other equipment, including pipettors, that may have been in contact with the contaminated cultures. It is recommended that potentially contaminated MSCs are sterilised using a suitable chemical fumigant. Using a liquid disinfectant alone may not be sufficient as it is difficult to reach all internal surfaces of an MSC with disinfectant. All media, media components and other reagents used for the contaminated cell lines must be discarded and all other cell lines in use within the laboratory should be quarantined and tested for mycoplasma to detect any spread of contamination.

\subsection{Contamination by other microorganisms}

With correct working practice it should not be necessary to use antibiotics to control contamination in established cell lines and their use should be discouraged. Microbial contamination may be obvious, indicating that the culture should be discarded, but, if antibiotics are used, contamination may be repressed but not eliminated. Such cryptic contamination may co-exist with the cell culture and only appear when the culture conditions change or the organism develops antibiotic resistance. In addition as antibiotics and antifungal agents act by inhibiting biochemical functions of the organism, these activities may also affect animal cells prejudicing the outcome of experiments. For example, amphotericin B is a membrane active agent and may therefore interfere with any mammalian cell experiments involving membrane trafficking or intercellular signalling.

\subsubsection{Bacteria and fungi}

If cells are cultured in antibiotic-free media as recommended, contamination by bacteria, yeast or fungi can usually be detected by an increase in turbidity of the medium and/or a change in $\mathrm{pH}$ (typically acidic with many bacteria giving a yellow colour change in media containing phenol red as a $\mathrm{pH}$ indicator but can be alkaline, pink, with some fungi). It is recommended that cells are inspected daily and must always be examined under an inverted phase microscope before use in an experiment.

The two methods generally used for bacterial and fungal detection are microbiological culture in special media and direct observation using Gram's stain, although bacterial infections may also be revealed during routine testing for mycoplasma by Hoechst 33258 staining. If necessary, the help of a hospital microbiology laboratory may be sought with identification and antibiotic sensitivity testing.

If a cell culture is contaminated with bacteria or fungi, then the best method of elimination is to discard the culture and initiate fresh cultures from frozen stock. In the case of irreplaceable stocks, it may be necessary to use antibiotics; the more antibiotics that are tested, the greater the chance of finding one that eliminates the infection. However, if the cells have been routinely grown in media supplemented with antibiotics (which is not recommended), it is almost certain that the contamination will be with organisms that are already resistant to this and some other antibiotics.

To eliminate infection, the cells should be cultured in quarantine (see Section 1.2.1) in the presence of the antibiotic for at least three passages. If the contamination appears to be 
Table 4. Laboratory surface disinfectants

\begin{tabular}{|c|c|c|c|c|c|}
\hline $\begin{array}{l}\text { Disinfectant } \\
\text { Class }\end{array}$ & Effective against & Advantages & Disadvantages & $\begin{array}{l}\text { Effect on other } \\
\text { materials }\end{array}$ & Examples \\
\hline Alcohols & \begin{tabular}{|l|} 
Bacteria \\
Enveloped virus \\
Non-enveloped virus
\end{tabular} & $\begin{array}{l}\text { Short contact times for } \\
\text { effective kill rates. } \\
\text { Cheap and easy to prepare. } \\
\text { Low toxicity. }\end{array}$ & $\begin{array}{l}\text { Flammable. } \\
\text { Limited activity against mycobacteria. } \\
\text { Not effective against spores. } \\
\text { Not effective against fungi. } \\
\text { Virucidal activity variable. } \\
\text { Poor penetration of organic material. }\end{array}$ & $\begin{array}{l}\text { Non-corrosive to metals } \\
\text { but may damage plastics } \\
\text { and rubber. }\end{array}$ & $\begin{array}{l}70 \% \text { ethanol } \\
70 \% \text { isopropyl } \\
\text { alcohol }\end{array}$ \\
\hline $\begin{array}{l}\text { Hypochlorites } \\
\text { (and halogen- } \\
\text { releasing } \\
\text { agents) }\end{array}$ & \begin{tabular}{|l|} 
Bacteria \\
Fungi \\
Spores \\
Enveloped virus \\
Non-enveloped virus \\
Prions
\end{tabular} & $\begin{array}{l}\text { Effective against most } \\
\text { microorganisms. } \\
\text { Effective against prions } \\
\text { Low toxicity. } \\
\text { Compatible with detergents. }\end{array}$ & $\begin{array}{l}\text { Toxic. } \\
\text { Limited activity against fungi. } \\
\text { Limited activity against mycobacteria. } \\
\text { Rapidly inactivated by organic matter. } \\
\text { Inactivated by anionic detergents. } \\
\text { Solutions decompose rapidly and } \\
\text { should be replaced frequently. }\end{array}$ & $\begin{array}{l}\text { Corrosive to metals and } \\
\text { rubber. } \\
\text { Will stain and bleach } \\
\text { fabrics and surfaces. }\end{array}$ & $\begin{array}{l}\text { Chloros } \\
\text { Presept }\end{array}$ \\
\hline Phenolics & \begin{tabular}{|l|} 
Bacteria \\
Fungi \\
Spores \\
Enveloped virus \\
Non-enveloped virus \\
Mycobacteria \\
\end{tabular} & $\begin{array}{l}\text { Effective against most } \\
\text { microorganisms. } \\
\text { Strong anti-fungal agent. }\end{array}$ & $\begin{array}{l}\text { Toxic skin irritant. } \\
\text { Not effective against some } \\
\text { non-enveloped viruses. } \\
\text { Inactivated by anionic detergents. } \\
\text { Inactivated by hard water/salts. } \\
\text { Strong odour. }\end{array}$ & $\begin{array}{l}\text { Slightly corrosive to } \\
\text { metals. } \\
\text { Can damage many } \\
\text { plastics. }\end{array}$ & Hycolin \\
\hline $\begin{array}{l}\text { Quaternary } \\
\text { ammonium } \\
\text { compounds }\end{array}$ & \begin{tabular}{|l|} 
Bacteria \\
Fungi \\
Enveloped virus \\
Non-enveloped virus \\
Mycobacteria
\end{tabular} & $\begin{array}{l}\text { Effective against most } \\
\text { microorganisms. } \\
\text { Low toxicity. }\end{array}$ & $\begin{array}{l}\text { Not effective against some } \\
\text { non-enveloped viruses. } \\
\text { Not effective against spores. } \\
\text { Long contact times required for } \\
\text { effective kill rates. } \\
\text { Inactivated by organic matter. } \\
\text { Inactivated by anionic detergents. } \\
\text { Activity reduced by hard water/salts. }\end{array}$ & $\begin{array}{l}\text { Minimally corrosive } \\
\text { Can stain surfaces. }\end{array}$ & $\begin{array}{l}\text { Trigene }^{1} \\
\text { Distel }^{1} \\
\text { Anistel }^{1} \\
\text { Chemgene HLD4 }^{1} \\
\text { MicroSol } 3+{ }^{2} \\
{\text { Klercide } \mathrm{A}^{1}}^{\text {Klercide }^{3}}\end{array}$ \\
\hline $\begin{array}{l}\text { Peroxygen } \\
\text { Compounds }\end{array}$ & \begin{tabular}{|l|} 
Bacteria \\
Fungi \\
Spores \\
Enveloped virus \\
Non-enveloped virus \\
\end{tabular} & $\begin{array}{l}\text { Effective against most } \\
\text { bacteria viruses and fungi. } \\
\text { Some activity against spores } \\
\text { and mycobacteria. }\end{array}$ & $\begin{array}{l}\text { Irritant. } \\
\text { Working solutions decompose and } \\
\text { should be replaced every few days. }\end{array}$ & $\begin{array}{l}\text { Corrosive but less than } \\
\text { hypochlorites. }\end{array}$ & Virkon \\
\hline $\begin{array}{l}\text { Notes: This chart } \\
\text { commercial prodi } \\
\text { ensure optimum } \\
\text { disinfectants it is } \\
\text { after the recomm } \\
\text { compounds and }\end{array}$ & $\begin{array}{l}\text { not intended to be a compr } \\
\text { ts are for information only w } \\
\text { tivity all surface disinfectants } \\
\text { est practice to alternate the } \\
\text { ided exposure times by wipir } \\
\text { amphoteric biocide. }{ }^{3} \mathrm{Coml}\end{array}$ & $\begin{array}{l}\text { rehensive list of all available surface c } \\
\text { vith no endorsement intended or imp } \\
\text { s should be used in accordance with } \\
\text { use of different classes of disinfectan } \\
\text { ng surfaces with } 70 \% \text { alcohol. }{ }^{1} \text { Combi } \\
\text { bination of a quaternary ammonium }\end{array}$ & $\begin{array}{l}\text { disinfectants, but is a summary of the properties } \\
\text { plied (also refer to the studies by McDonnell an } \\
\text { the manufacturer's instructions. In order to dis } \\
\text { tover time. To prevent corrosion, particularly or } \\
\text { ination of a quaternary ammonium compounds } \\
\text { compounds and chlorine dioxide. }\end{array}$ & $\begin{array}{l}\text { of those most commonly used } \\
\text { d Denver Russell (1999) and Ru } \\
\text { courage the development of cor } \\
n \text { metal surfaces, residual disinfe } \\
\text { and a biguanide. }{ }^{2} \text { Combination }\end{array}$ & $\begin{array}{l}\text { n UK laboratories. Name } \\
\text { ala and Weber (2008)). T } \\
\text { taminants resistant to th } \\
\text { ctants should be remove } \\
\text { ff a quaternary ammoniur }\end{array}$ \\
\hline
\end{tabular}

eradicated, a sample of the culture should be cryopreserved and the remaining cells cultured in antibiotic-free medium for 1 month before re-testing. If clear, the preserved stock can then be used to generate an archive frozen stock for future work; if not, a different antibiotic can be used. It is important to remember that the more antibiotics that are used and fail the more dangerous the organism becomes as a potential contaminant of other cultures.

\subsubsection{Viruses}

As long as cell culture reagents of biological origin are used, such as serum to supplement media and natural trypsin for subculture, there will always be a risk that endogenous infections in the source of the reagent will infect the culture. Any viral contaminant that grows in the cells will affect the cells' metabolism and could also present a safety hazard to lab workers. The source of viral contamination can be from the tissue from which the cells are derived (e.g., HIV from Kaposi's sarcoma cells, EBV from lymphoma cells). Alternatively, contamination can be derived from other infected cultures or, as a more remote possibility, from laboratory personnel. Another route of infection can be during passage of cells in experimental animals, important when considering the use of cell lines for or from implantation of xenograft tumours. Not only do the cells to be implanted need to be free from contamination by extraneous viruses but also the animals into which the transplant is to be made should not harbour viruses that could affect the growth and response to therapy of the cells under study.

Even more than with mycoplasma, elimination of viral contamination is difficult and is likely to be impossible. However, what is worse, there are no simple universal diagnostic tests to identify viral contamination. Next-generation sequencing techniques potentially offer such screening but are yet to be qualified for routine safety testing. Identifying viruses currently necessitates screening with a wide panel of immunological or molecular probes and may be best done by a specialist testing service. As yet, such testing is largely restricted to human pathogens such as EBV, HIV, HTLV I/II and Hepatitis B \& C, and few laboratories screen for animal viruses on a routine basis, although some commercial suppliers and veterinary laboratories do. Use of serum-free medium and recombinant trypsin should help to minimise viral infection from reagents and GCCP will minimise the risk of transmission from one culture to another or to the person handling that culture. 


\subsubsection{Prions}

Transmissible spongiform encephalopathy (TSE), including what is known as bovine spongiform encephalopathy, BSE, or mad cow disease, is unlikely to be present in cancer cells or tissue culture products. Risks of prion contamination may need to be considered when using cell lines from the CNS or from patients with certain diseases associated with abnormal prion expansion. It should be noted that prions are not destroyed by autoclaving or by most chemical disinfectants. Disposal into $10 \%$ hypochlorite followed by incineration is recommended for any contaminated material.

\subsection{Genetic instability and phenotypic drift}

Two other major problems that can affect the utility of cell lines are genetic instability and phenotypic drift, both of which may progress the longer the cell line is cultured. Records should be kept of the length of time a cell line has been kept in culture. For finite cell lines, this is determined by the generation number, the number of doublings since isolation (necessarily approximate as it is difficult to measure the number of doublings in the primary culture). This number will determine the lifespan of the culture as most finite cell lines will die out due to senescence at between 20 and 60 doublings, which means that they can only be used reproducibly between 15 and 45 generations depending on the cell type. Cells are frozen at the lowest generation number possible and used to replace stocks at regular intervals before the onset of senescence. When thawed the generation number resumes at one over the number at freezing. For continuous cell lines, the number of passages since last thawed from the freezer is recorded. If the passage level at freezing is known, this may be added on but often this is not known.

\subsubsection{Genetic instability}

The chromosomal content of most continuous cell lines is both aneuploid (abnormal chromosome content) and heteroploid (variable chromosome content within the population). Many cancer cell lines have defects in p53 and other genes that monitor and repair DNA damage, resulting in an increased mutation frequency. Hence, the genotype of continuous cell lines can change with time and cell lines should not therefore be maintained for extended periods of time in continuous culture (Wenger et al, 2004; Saito et al, 2011).

In general, cell lines derived from normal tissue tend to have a chromosomal content typical of the karyotype for the species of origin. Most normal human cell lines will senesce and cease proliferation without major heritable changes in the genotype. In contrast, rodent cell lines, particularly mouse lines, become unstable and immortalise readily. It is important to check for any critical subculture or other handling measures for any new cell line. For example, immortal cell lines, such as 3T3, can retain their established growth characteristics provided that the recommended maintenance procedures are adhered to. In particular, they should not be allowed to become confluent, but should be subcultured from mid-log phase, and replaced regularly from frozen stock. They require constant monitoring to ensure that transformed variants, readily detected morphologically by their more refractile appearance and lack of contact inhibition, do not overgrow.

\subsubsection{Phenotypic instability}

Lack of expression of the differentiated properties of the cells of origin is a major recurrent problem. This can be due to selection of the wrong cell lineage in inappropriate culture conditions. For example, a disaggregated skin biopsy will ultimately give rise to a fibroblastic population that overgrows the epidermal keratinocytes, unless selective conditions are used. However, even under selective conditions, the need for propagation stimulates cell proliferation rather than differentiation. This process can either select undifferentiated cells or can lead to a loss of differentiated characteristics. In some cases, such as fibroblasts or endothelial cells, this is due to dedifferentiation, but in others, such as mammary epithelium, it is probably due to propagation and expansion of the progenitor cell compartment, which lacks the differentiated characteristics.

\subsubsection{Stability of stem cell lines}

There are particular problems associated with cell lines derived from stem cells, whether embryonic, fetal, adult or iPSCs:

(1) Phenotypic stability is dependent on the medium, particularly on cytokines and the activity of specific signalling pathways. For example, most mouse embryonic stem cell cultures will tend to differentiate spontaneously unless the stem cell phenotype is maintained with LIF or a feeder layer that produces it.

(2) If allowed to differentiate, the resultant phenotype is controlled by regulatory factors in the medium, such as retinoic acid or tetradecanoylphorbol acetate (TPA), and the microenvironment, e.g., by the cell density, extracellular matrix and signalling between cell types. Therefore, the plasticity of the phenotype, while not insignificant in other cell lines, is of particular importance in culturing stem cells, such as ESC and iPSC, and any other progenitor-type cell line that is induced to differentiate for experimental use (e.g., HL60, NB4 and SH-SY5Y).

(3) It is not entirely clear whether mesenchymal stem cells are inherently prone to genetic instability and transformation or are made so by genetic manipulation. Some reports claim transformation does not occur (Bernardo et al, 2007; Choumerianou et al, 2008), whereas others claimed that it does (Ren et al, 2011, 2012), although this can be due to crosscontamination (Torsvik et al, 2010, 2012). Mesenchymal stem cells (often now termed mesenchymal stromal cells) usually do not have a clonal origin and this heterogeneity may explain differences in results. Pluripotent stem cell lines (i.e., human ESCs and human iPSCs), which are usually clonal in origin, are well known to be susceptible to developing chromosomal changes and need to be periodically checked for genetic integrity. Again, it is rare cells in the population that acquire a growth advantage, often at the expense of ability to differentiate, that take over the culture. Culture conditions that are suboptimal are especially prone to this. Re-cloning the cells and screening for sublines with normal karyotypes can work, otherwise reverting to an earlier passage is recommended.

(4) As for any other cell lines, authentication of stem cell lines is essential, and genotypic and phenotypic instability must be assessed.

Examination of processes that depend on the expression of the in vivo phenotype, whether normal or neoplastic, may require modifications to culture conditions (e.g., high cell density, growth factors, low serum, position at the air-liquid interface, heterologous cell interaction and extracellular matrix), which usually are incompatible with cell proliferation. Hence, different conditions need to be defined for culture of a cell line dependent on whether cell proliferation or cell differentiation is required. It is important and probably essential for comparative purposes that different laboratories using the same cell line should match their culture conditions as closely as possible. 


\section{TROUBLESHOOTING}

Section 5. Summary

- Approach problem-solving in a systematic manner.

- Start by looking at what changes have been made: equipment, reagents and media.

- Ensure proper records are made of the nature of the problem and how it was solved.

- Keep everyone using the facility or equipment informed of the problem and its solution.

Even with full attention to these Guidelines and/or other established rules of good practice (Coecke et al, 2005; Freshney, 2010; Davis, 2011), every laboratory will, from time to time, encounter problems ranging from widespread fungal contamination to quite subtle deviations from normal patterns of cell growth. When such problems occur, a logical and systematic approach should be taken to identifying and removing the causes.

Without good background information, assessment of a problem can be unnecessarily difficult or impossible. Careful logging of reagent batch numbers used to make each bottle of medium may often seem pedantic and time-consuming, but can prove invaluable when problems occur. Similarly, careful documentation of the normal behaviour of a cell line provides essential background information. This can include records of cell counts at subculture and occasional photographs of growing cultures ideally at both low- and high cell population density.

The following general approach to troubleshooting may prove useful:

(1) Once the existence of a problem is suspected, it is important to define its characteristics and inform all those who may be affected.

(2) If the nature of the problem is readily identified (e.g., a defective incubator), make sure by appropriate means that its existence is known (e.g., a large notice on the incubator) and that the person responsible is dealing with the problem.

(3) Less obvious problems will need a more comprehensive survey of the facts. This may be facilitated by a meeting of all those involved, as even apparently quite trivial observations may be relevant.

(4) Once the problem is identified, it should be possible to draw up a list of possible causes in order of probability.

(5) It is often useful to ask 'what is new?' in terms of reagents, including plasticware, equipment or procedures, or even new staff, which may coincide with the problem. Be aware, however, of possible time displacements such as the effects of a minimally substandard medium batch only becoming manifest after several cell generations, with some cell lines being more sensitive than others.

(6) When switching to a new batch of any medium component (including serum), even though this has been batch-tested, retain a reasonable amount of the old batch for some period of time. This will allow head-to-head testing should problems arise when the new batch is introduced.

(7) With problems of deficient cell growth and/or unusual appearance, the problem may lie with the cells, the growth medium, the growth environment or some combination of these. Clues as to which of these to pursue first may come from which cell lines are affected. Do they share an incubator? Do they have a common medium? Are they using the same culture vessels? Have preparation or culture procedures changed?
(8) If a particular cell line is affected, and tests for contamination (bacteria, mycoplasma) are negative, a vial of the cell line should be taken from frozen stock and the old and new cells tested head-to-head over several passages. If the old cells continue to do badly and the new cells grow normally, then the old cell stock should be discarded and the new stock used for future work. If both stocks do badly then the problem probably lies elsewhere (virtually all cell lines take a period of time to recover from being frozen, so this needs to be taken account of when comparing growth patterns). In addition, a genotyping test such as STR profiling should be performed to rule out a possible misidentification. Sterility testing (inoculation of medium from the culture into broth or agar at normal culture temperature and also at $20-25^{\circ} \mathrm{C}$, in order to isolate microorganisms that grow best at lower temperatures) is worth considering to rule out contamination with a slowgrowing microorganism.

(9) Where a problem with the medium appears to be present, a series of tests should be set up in which head-to-head growth comparisons are made in different media where only one medium component at a time is changed. Basal medium can also be obtained from an alternative supplier and compared. Although serum and basal medium may be the most obvious sources of problems, other components including water, glutamine and antibiotics are also candidates.

(10) If a problem component is identified, the finding should be discussed with the supplier who may be able to state that the batch has been used by many other laboratories without problems or (occasionally and off-the-record) that there may be a problem with a batch.

(11) Where problems of contamination are encountered, again the first step is to look for any changes in procedures, sources of materials and staff. The records from sterilisation equipment should be checked, and the medium and its components incubated to see whether contamination appears. Determine whether the problem is confined to one person, cell line, incubator or MSC, or is more general. General problems tend to implicate equipment or ventilation failure while specific problems may relate more to a particular specialised reagent or procedure or even to technical lapses of one individual.

(12) In the experience of many workers, growth problems sometimes are never satisfactorily solved, but the cells begin, after some time, to resume normal growth. Such problems may, however, recur and the combined experience of the first and second episodes may be helpful in further investigation. Similarly, problems of contamination often go away without a specific cause ever being identified. A crowded lab will be particularly susceptible and will need strict enforcement of the rules of aseptic technique.

\section{ACKNOWLEDGEMENTS}

We would like to acknowledge Cancer Research UK for funding our authors' meetings during the preparation of these guidelines. 


\section{REFERENCES}

Advisory Committee on Dangerous Pathogens (ACDP) (2004) The approved list of biological agents. Health and Safety Executive. www.hse.gov.uk.

Advisory Committee on Dangerous Pathogens (ACDP) (2005) Biological agents: managing the risks in laboratories and healthcare premises. Health and Safety Executive. www.hse.gov.uk.

American National Standards Institute (2011) Authentication of human cell lines: standardization of STR profiling. ANSI/ATCC ASN-0002-2011. http://webstore.ansi.org.

BBC News (2000) Safety problems led to lab death. http://news.bbc.co.uk/1/hi/ scotland/798925.stm.

Bandi S, Akkina R (2008) Human embryonic stem cell (hES) derived dendritic cells are functionally normal and are susceptible to HIV-1 infection. AIDS Res Ther 5: 1-7.

Bernardo ME, Zaffaroni N, Novara F, Cometa AM, Avanzini MA, Moretta A, Montagna D, Maccario R, Villa R, Daidone MG,

Zuffardi O, Locatelli F (2007) Human bone marrow derived mesenchymal stem cells do not undergo transformation after long-term in vitro culture and do not exhibit telomere maintenance mechanisms. Cancer Res 67(19): 9142-9149.

Bertout JA, Patel SA, Simon MC (2008) The impact of $\mathrm{O}_{2}$ availability on human cancer. Nat Rev Cancer 8(12): 967-975.

Birney E, Andrews TD, Bevan P, Caccamo M, Chen Y, Clarke L, Coates G, Cuff J, Curwen V, Cutts T, Down T, Eyras E, Fernandes-Suarez XM, Gane P, Gibbins B, Gilbert J, Hammond M, Hotz H-R, Iyer V, Jekosch K, Kahara A, Kasprzyk A, Keefe D, Keenan S, Lehvaslaiho H, McVicker G, Melsopp C, Meidl P, Mongin E, Pettett R, Potter S, Proctor G, Rae M, Searle S, Slater G, Smedley D, Smith J, Spooner W, Stabenau A, Stalker J, Storey R, Ureta-Vidal A, Woodwark KC, Cameron G, Durbin R, Cox A, Hubbard T, Clamp M (2004) An overview of Ensembl. Genome Res 14(5): 925-928.

British Standards Institute (2000) BS EN 12469:2000. Biotechnology performance criteria for microbiological safety cabinets. http://shop bsigroup.com.

British Standards Institute (2005) BS 5726:2005. Microbiological safety cabinets. Information to be supplied by the purchaser to the vendor and to the installer, and siting and use of cabinets. Recommendations and guidance. http://shop.bsigroup.com.

Caldicott R (2013) Caldicott review 2013. To share or not to share? Department of Health. www.gov.uk.

CDC (2008) Healthcare Infection Control Policies Advisory Committee Centers for Disease Control and Prevention - Guideline for Disinfection and Sterilisation in Healthcare Facilities. Centres for Disease Control and Prevention: Atlanta, GA, USA 30333. www.cdc.gov/hicpac/ Disinfection_Sterilization/toc.html.

Choumerianou DM, Dimitriou H, Perdikogianni C, Martimianaki G, Riminucci M, Kalmanti M (2008) Study of oncogenic transformation in ex vivo expanded mesenchymal cells, from paediatric bone marrow. Cell Prolif 41(6): 909-922.

Coecke S, Balls M, Bowe G, Davis J, Gstraunthaler G, Hartung T, Hay R, Merten OW, Price A, Schechtman L, Stacey G, Stokes W (2005) Guidance on good cell culture practice. A report of the second ECVAM task force on good cell culture practice. Altern Lab Anim 33(3): 261-287.

Cooper JK, Sykes G, King S, Cottrill K, Ivanova NV, Hanner R, Ikonomi P (2007) Species identification in cell culture: a two-pronged molecular approach. In Vitro Cell Dev Biol Anim 43(10): 344-351.

Control of Substances Hazardous to Health (COSHH) (2013) The Control of Substances Hazardous to Health Regulations 2002 (as amended), 6th edn. HSE Books: Sudbury, UK. www.hse.gov.uk.

Czarneski MA, Lorcheim K (2011) A discussion of biological safety cabinet decontamination methods: formaldehyde, chlorine dioxide and vapor phase hydrogen peroxide. Appl Biosafety 16(1): 26-33.

DAFF (2013) Australian Government Department of Agriculture. Import permit for biological products. www.daff.gov.au/biosecurity.

Davis JM (2011) Animal Cell Culture: Essential Methods. Wiley-Blackwell, John Wiley \& Sons: Chichester, UK. doi:10.1002/9780470669815.

Drexler HG, Matsuo Y (1999) Guidelines for the characterisation and publication of human malignant hematopoietic cell lines. Leukemia 13(6): 835-842.
Drexler HG, Uphoff CC (2002) Mycoplasma contamination of cell cultures: Incidence, sources, effects, detection, elimination, prevention. Cytotechnology 39(2): 75-90.

EMA (2007) European Medicines Agency, Committee for Human Medicinal Products (CHMP). Guideline on Human Cell-Based Medicinal Products. EMEA/CHMP/410869/2006. www.ema.europa.eu.

EMA (2013) European Medicines Agency, Committee for Advanced Therapies (CAT). www.ema.europa.eu.

Environmental Protection Act (1990) UK Government. Environmental Protection Act 1990. www.legislation.gov.uk/ukpga/1990/43/contents.

EU Directives (2010) Diective 2010/63/EU of the European Parliament and of the Council of 22 September 2010 on the protection of animals used for scientific purposes. http://new.eur-lex.europa.eu.

FDA (2010) US Department of Health and Human Services, Food and Drug Administration Centre for Biologic Evaluation and Research. Guidance for industry characterisation and qualification of cell substrates and other biological materials used in the production of viral vaccines for infectious disease Indications. www.fda.gov/BiologicsBloodVaccines/ GuidanceComplianceRegulatoryInformation/Guidances/default.htm.

Finkel E (2007) Research safety. Inquest flags little-known danger of high-containment labs. Science 316(5825): 677.

Freshney RI (2002) Cell line provenance. Cytotechnology 39(2): 55-67.

Freshney RI (2010) Culture of animal cells: a manual of basic technique and specialized applications. 6th edn. Wiley-Blackwell: New York, NY, USA.

Gartler SM (1967) Genetic markers as tracers in cell culture. Second Decennial Review Conference on Cell, Tissue and Organ Culture; NCI Monograph, NCI, Washington, DC, WA, USA, pp 167-195.

Gugel EA, Sanders ME (1986) Needle-stick transmission of human colonic adenocarcinoma. New Engl J Med 315(23): 1487-1986.

Hazardous waste (2004-9) European: Directive on Waste 2008/98/EC England and Wales: The Hazardous Waste (England and Wales) (Amendment) Regulations 2009 (Statutory Instrument SI507). www.legislation.gov.uk/uksi/2009/507. Scotland: The Special Waste Amendment (Scotland) Regulations 2004 (SSI 2004 no 112), www.legislation.gov.uk/ssi/2004/112. Northern Ireland: Hazardous Waste Regulations (Northern Ireland) 2005 (Statutory Rules of Northern Ireland 2005 No. 300. www.legislation.gov.uk/nisr/2005/300.

HFEA (2001) UK Statutory Instruments 2001 No. 188 Human Fertilisation and Embryology. The Human Fertilisation and Embryology (Research Purposes) Regulations 2001. www.legislation.gov.uk.

HFEA (2008) UK Government. Human Fertilisation and Embryology Act 2008. www.legislation.gov.uk/ukpga/2008/22.

HFEA (2013) The Human Fertilisation and Embryology Authority Code of Practice, 8th edn. www.hfea.gov.uk.

Home Office (2012) Animals (Scientific Procedures) Act 1986 Amendment Regulations (2012). www.legislation.gov.uk/ukdsi/2012/9780111530313.

HSE (1974) UK Government. Health and Safety at Work etc. Act 1974. www.legislation.gov.uk/ukpga/1974/37.

Health \& Safety Executive (HSE) (1992) Rupture of a Liquid Nitrogen Storage Tank, Japan. 28th August 1992. Accident Summary. http://www.hse. gov.uk/comah/sragtech/caseliqnitro92.htm.

Health and Safety Executive (HSE) (1999) Management of health and safety at work. Management of Health and Safety at Work Regulations 1999. Approved Code of Practice and guidance. HSE Books, Sudbury, UK. www.hse.gov.uk.

Health and Safety Executive (HSE) (2000) A Guide to the Genetically Modified Organisms (Contained Use) Regulations 2000. HSE Books, Sudbury, UK. www.hse.gov.uk.

HSE (2001) Health and Safety Executive. The Management, Design and Operation of Microbiological Containment Laboratories. HSE Books: Sudbury, UK. www.hse.gov.uk.

HSE (2005) Health and Safety Executive. Control of substances hazardous to health (5th edn). The Control of Substances Hazardous to Health Regulations 2002 (as amended). Approved Code of Practice and guidance. HSE Books: Sudbury, UK. www.hse.gov.uk.

Health and Safety Executive (HSE) (2012) Safety requirements for autoclaves. Guidance Note PM73 (rev3). www.hse.gov.uk.

HT Act (2004) Human Tissue Act (2004). www.legislation.gov.uk/ukpga/2004/30. HTA (2007) Human Tissue (Quality and Safety for Human Application) Regulations 2007. www.legislation.gov.uk/uksi/2007/1523. 
HTA (2013) Human Tissue Authority. www.hta.gov.uk.

Human Tissue (Scotland) Act (2006) Human Tissue (Scotland) Act 2006. www.legislation.gov.uk/asp/2006/4.

Hummeler K, Davidson WL, Henle W, LaBoccetta AC, Ruch HG (1959) Encephalomyelitis due to infection with Herpesvirus simiae (Herpes B virus): a report of two fatal, laboratory-acquired cases. New Engl J Med 261(2): 64-68.

Hunt CJ (2011) Cryopreservation of human stem cells for clinical application: a review. Transfus Med Hemother 38(2): 107-123.

IATA (2013) International Air Transport Association. Dangerous Goods Regulations (DGR). www.iata.org.

ICH (2013) The International Conference on Harmonisation of Technical Requirements for Registration of Pharmaceuticals for Human Use. www.ich.org.

ICLAC (2013a) International Cell Line Authentication Committee. Database of cross-contaminated and misidentified cell lines. http://iclac.org/ databases/cross-contaminations/.

ICLAC (2013b) International Cell Line Authentication Committee. Advice to scientists. http://iclac.org/resources/advice-scientists/.

IRAS (2013) Integrated Research Application System. www.myresearchproject. org.uk.

Isasi R, Knoppers BM, Andrews PW, Bredenoord A, Colman A, Hin LE, Hull S, Kim OJ, Lomax G, Morris C, Sipp D, Stacey G, Wahlstrom J, Zeng F. International Stem Cell Forum Ethics Working Party (2012) Disclosure and management of research findings in stem cell research and banking: policy statement. Regen Med 7(3): 439-448.

Lengner CJ, Gimelbrant AA, Erwin JA, Cheng AW, Guenther MG, Welstead GG, Alagappan R, Frampton GM, Xu P, Muffat J, Santagata S, Powers D, Barrett CB, Young RA, Lee JT, Jaenisch R, Mitalipova M (2010) Derivation of pre-X inactivation human embryonic stem cells under physiological oxygen concentrations. Cell 141(5): 872-883.

Lloyd G, Jones N (1984) Infection of laboratory workers with hantavirus acquired from immunocytomas propagated in laboratory rats. J Infect 12(2): 117-125.

Lovell-Badge R (2008) The regulation of human embryo and stem cell research in the United Kingdom. Nat Rev Mol Cell Biol 9(12): 998-100.

Luong MX, Auerbach J, Crook JM, Daheron L, Hei D, Lomax G, Loring JF, Ludwig T, Schlaeger TM, Smith KP, Stacey G, Xu RH, Zeng F (2011) A call for standardized naming and reporting of human ESC and iPSC lines. Cell Stem Cell 8(4): 357-359.

MacLeod RAF, Drexler HG (2005) Cytogenetic analysis of cell lines. In Methods in Molecular Biology 290: Basic Cell Culture Protocols, Helgason CD, Miller CL (eds), 3rd edn, pp 51-70. Human Press: Totowa, NJ, USA.

McDonnell G, Russell AD (1999) Antiseptics and disinfectants: activity, action and resistance. Clin Microbiol Rev 12(1): 147-179.

MHRA (2004a) Medicines for Human Use (Clinical Trials) Regulations 2004. www.legislation.gov.uk/uksi/2004/1031.

MHRA (2004b) EU Clinical Trials Directive 2001/20/EC. http://ec.europa.eu/ health/human-use/clinical-trials/index_en.htm.

MHRA (2007) Rules and Guidance for Pharmaceutical Manufacturers and Distributors. Pharmaceutical Press: London, UK.

MHRA (2013) Medicines and Healthcare Products Regulatory Agency. www.mhra.gov.uk.

MRC (2009) UK Stem Cell Toolkit. www.sc-toolkit.ac.uk.

MRC (2013) Steering Committee for the UK Stem Cell Bank and for the Use of Stem Cell Lines. www.mrc.ac.uk.

MRC (2013) Medical Research Council. www.mrc.ac.uk.

NCBI (2013) National Center for Biotechnology Information. Database of human cell line STR profiles. www.ncbi.nlm.nih.gov/ biosample?term=human\%20cell\%20line\%20STR\%20profile.

Nelson-Rees WA, Flandermeyer RR (1976) HeLa cultures defined. Science 191(4222): 1343-1344.

Nelson-Rees WA, Flandermeyer RR (1977) Inter- and intracspecies contamination of human breast tumor cell lines $\mathrm{HBC}$ and $\mathrm{BrCa} 5$ and other cell cultures. Science 195(4284): 1343-1344.

NHS (2013) National Health Service, Health Research Authority. www.hra.nhs.uk.

NIHR (2013) National Institute for Health Research. Clinical Trials Toolkit. www.ct-toolkit.ac.uk.

NRES (2013) National Research Ethics Service. www.nres.nhs.uk.

O'Donoghue LE, Rivest JP, Duval DL (2011) Polymerase chain reaction-based species verification and microsatellite analysis for canine cell line validation. $J$ Vet Diagn Invest 23(4): 780-785.
OHRP (2011) Office for Human Research Protections. www.hhs.gov/ohrp/.

OLAW (2013) Office of Laboratory Animal Welfare. http:/grants.nih.gov/ grants/olaw/olaw.htm.

Ozturk SS, Palsson BO (1990) Chemical decomposition of glutamine in cell culture media: effect of media type, $\mathrm{pH}$ and serum concentration. Biotechnol Prog 6(2): 121-128.

PCSBI (2013) Presidential Commission for the Study of Bioethical Issues. www.bioethics.gov.

Ren Z, Wang J, Zhu W, Guan Y, Zou C, Chen Z, Zhang YA (2011) Spontaneous transformation of adult mesenchymal stem cells from cynomolgus macaques in vitro. Exp Cell Res 317(20): 2950-2957.

Ren Z, Zhang YA, Chen Z (2012) Spontaneous transformation of cynomolgus mesenchymal stem cells in vitro: further confirmation by short tandem repeat analysis. Exp Cell Res 318(5): 435-440.

Rutala WA, Weber DJ. and the Healthcare Infection Control Practices Advisory Committee (2008) Guidelines for Disinfection and Sterilisation in Healthcare Facilities 30333. Centres for Disease Control and Prevention (CDC) publications: Atlanta, GA.

Saito S, Morita K, Kohara A, Masui T, Sasao M, Ohgushi H, Hirano T (2011) Use of BAC array CGH for evaluation of chromosomal stability of clinically used human mesenchymal stem cells and of cancer cell lines. Hum Cell 24(1): 2-8.

Schaeffer WI (1990) Terminology associated with cell, tissue and organ culture, molecular biology and molecular genetics. Tissue Culture Association Terminology Committee. In vitro Cell Dev Biol 26(1): 97-101.

Schmid I, Lambert C, Ambrozak D, Marti GE, Moss DM, Perfetto SP. International Society of Analytical Cytology (2007a) International Society for Analytical Cytology biosafety standard for sorting of unfixed cells. Cytometry 71(6): 414-437.

Schmid I, Lambert C, Ambrozak D, Perfetto SP (2007b) Standard safety practices for sorting of unfixed cells. Curr Protoc Cytom Jan; Chapter 3:Unit3.6, doi:10.1002/0471142956.cy0306s39.

Si-Tayeb K, Duclos-Vallée JC, Petit MA (2012) Hepatocyte-like cells differentiated from human induced pluripotent stem cells (iHLCs) are permissive to hepatitis $\mathrm{C}$ virus (HCV) infection: $\mathrm{HCV}$ study gets personal. J Hepatol 57(3): 689-691.

Stephens JK, Everson GT, Elliot CL, Kam I, Wachs M, Haney J, Bartlett ST, Franklin WA (2000) Fatal transfer of malignant melanoma from multiorgan donor to four allograft recipients. Transplantation 70(1): 232-236.

Stacey GN, Doyle A (1997) Master cell banking. In Procedures in Cell and Tissue Culture, 31A Standardisation, 31A1, Doyle A, Griffiths JB, Newell DG (eds). Wiley and Sons: Chichester, UK.

Tedder RS, Zuckerman MA, Goldstone AH, Hawkins AE, Fielding A, Briggs EM, Irwin D, Blair S, Gorman AM, Patterson KG (1995) Hepatitis B transmission from a contaminated cryopreservation tank. Lancet 346(8968): 137-140.

Torsvik A, Røsland GV, Bjerkvig R (2012) Comment to: "Spontaneous transformation of adult mesenchymal stem cells from cynomolgus macaques in vitro" by Z. Ren et al. Exp. Cell Res. 317 (2011) 2950-2957: Spontaneous transformation of mesenchymal stem cells in culture: facts or fiction? Exp Cell Res 318(5): 441-443.

Torsvik A, Røsland GV, Svendsen A, Molven A, Immervoll H, McCormack E, Lønning PE, Primon M, Sobala E, Tonn JC, Goldbrunner R, Schichor C, Mysliwietz J, Lah TT, Motaln H, Knappskog S, Bjerkvig R (2010) Spontaneous malignant transformation of human mesenchymal stem cells reflects cross-contamination: putting the research field on track - letter. Cancer Res 70(15): 6393-6396.

Tuly JG, Razin S (1996) Molecular and Diagnostic Procedures in Mycoplasmology. Academic Press: San Diego, CA, USA.

UKCCCR (2000) Guidelines for the use of cell lines in cancer research. Br J Cancer 82(9): 1495-1509.

UK Government Department for Environment, Food and Rural Affairs. (DEFRA) (2013) Import permit for biological products. Available at: defra.helpline@defra.gsi.gov.uk. London, UK.www.gov.uk/defra.

UKSCB (2013) UK Stem Cell Bank. www.ukstemcellbank.org.uk.

Uphoff CC, Brauer S, Grunicke D, Gignac SM, MacLeod RA, Quentmeier H, Steube K, Tümmler M, Voges M, Wagner B, Drexler HG (1992) Sensitivity and specificity of five different mycoplasma detection assays. Leukemia 6(4): $335-341$.

USDA (2012) United States Department of Agriculture, Animal and Plant Health Inspection Service. Animal Health Permits. http://www.aphis.usda.gov/permits/index.shtml. 
Wenger SL, Senft JR, Sargent LM, Bamezai R, Bairwa N, Grant SG (2004) Comparison of established cell lines at different passages by karyotype and comparative genomic hybridization. Biosci Rep 24(6): 631-639.

Whitehead P (2007) Water purity and regulations. In Medicines from Animal Cell Culture, Stacey G, Davis JM (eds), pp 17-27. Wiley: Chichester, UK.

Workman P, Aboagye EO, Balkwill F, Balmain A, Bruder G, Chaplin DJ, Double JA, Everitt J, Farningham DAH, Glennie MJ, Kelland LR,

Robinson V, Stratford IJ, Tozer GM, Watson S, Wedge SR, Eccles SA, Navaratnam V, Ryder S. Natl Canc Res Inst [Group Author] (2010) Guidelines for the welfare and use of animals in cancer research. Br J Cancer 102(11):1555-1577.

World Health Organisation (WHO) (2013) Recommendations for the evaluation of animal cell cultures as substrates for the manufacture of biological medicinal products and for the characterisation of cell banks. Replacement of Annex 1 of WHO Technical Report Series, No. 878. In: WHO Expert Committee on Biological Standardization. Sixty-first report. World Health Organization. Geneva, Switzerland (WHO Technical Report Series, No 978, Annex 3).

Zou S, Dodd RY, Stramer SL, Strong DM (2004) Probability of viremia with HBV, HCV, HIV, and HTLV among tissue donors in the United States. New Engl J Med 351: 751-759.

(c) (i) (2) (2) This work is licensed under the Creative Commons BY NC SA Attribution-NonCommercial-Share Alike 3.0 Unported License. To view a copy of this license, visit http://creativecommons. org/licenses/by-nc-sa/3.0/ 